\title{
Southeast Regional Carbon Sequestration Partnership
}

(SECARB)

\section{Identification of the Most Promising \\ Capture, Sequestration, and Transport Options \\ and \\ Preparation of Action Plans for the SECARB Geographic Region}

Report Type:

Reporting Period End Date:

DOE Award Number:

Submitting Organization:
Semiannual Technical Report

September 30, 2005

DE-FC26-03NT41980

Southern States Energy Board

6325 Amherst Court

Norcross, GA 30092 


\section{Disclaimer}

This report was prepared as an account of work sponsored by an agency of the United States Government. Neither the United States Government nor any agency thereof, nor any of their employees, makes any warranty, express or implied, or assumes any legal liability or responsibility for the accuracy, completeness, or usefulness of any information, apparatus, product, or process disclosed, or represents that its use would not infringe privately owned rights. Reference herein to any specific commercial product, process, or service by trade name, trademark, manufacturer, or otherwise does not necessarily constitute or imply its endorsement, recommendation, or favoring by the United States Government or any agency thereof. The views and opinions of authors expressed herein do not necessarily state or reflect those of the United States Government or any agency thereof. 


\section{Table of Contents}

1.0 Identification of the Most Promising Capture, Sequestration, and Transport Options......................................................................................... 4

$2.0 \mathrm{CO}_{2}$ Sequestration Opportunities ........................................................ 9

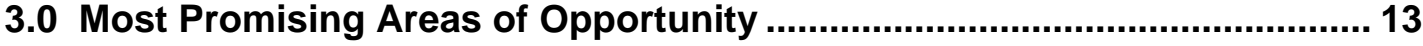

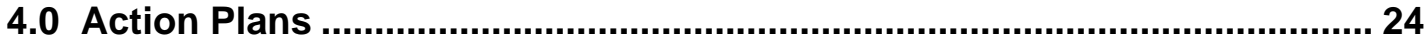

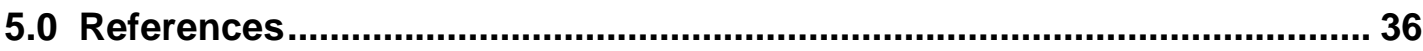




\subsection{Identification of the Most Promising Capture, Sequestration, and Transport Options}

\subsection{Scope and Overview}

The Southeast Regional Carbon Sequestration Partnership (SECARB) is a diverse partnership covering eleven states involving the Southern States Energy Board (SSEB) an interstate compact; regulatory agencies and/or geological surveys from member states; the Electric Power Research Institute (EPRI); academic institutions; a Native American enterprise; and multiple entities from the private sector. Figure 1 shows the team structure for the partnership. In addition to the Technical Team, the Technology Coalition, an alliance of auxiliary participants, in the project lends yet more strength and support to the project. The Technology Coalition, with its diverse representation of various sectors, is integral to the technical information transfer, outreach, and public perception activities of the partnership. The Technology Coalition members, shown in Figure 2, also provide a breadth of knowledge and capabilities in the multiplicity of technologies needed to assure a successful outcome to the project and serve as an extremely important asset to the partnership.

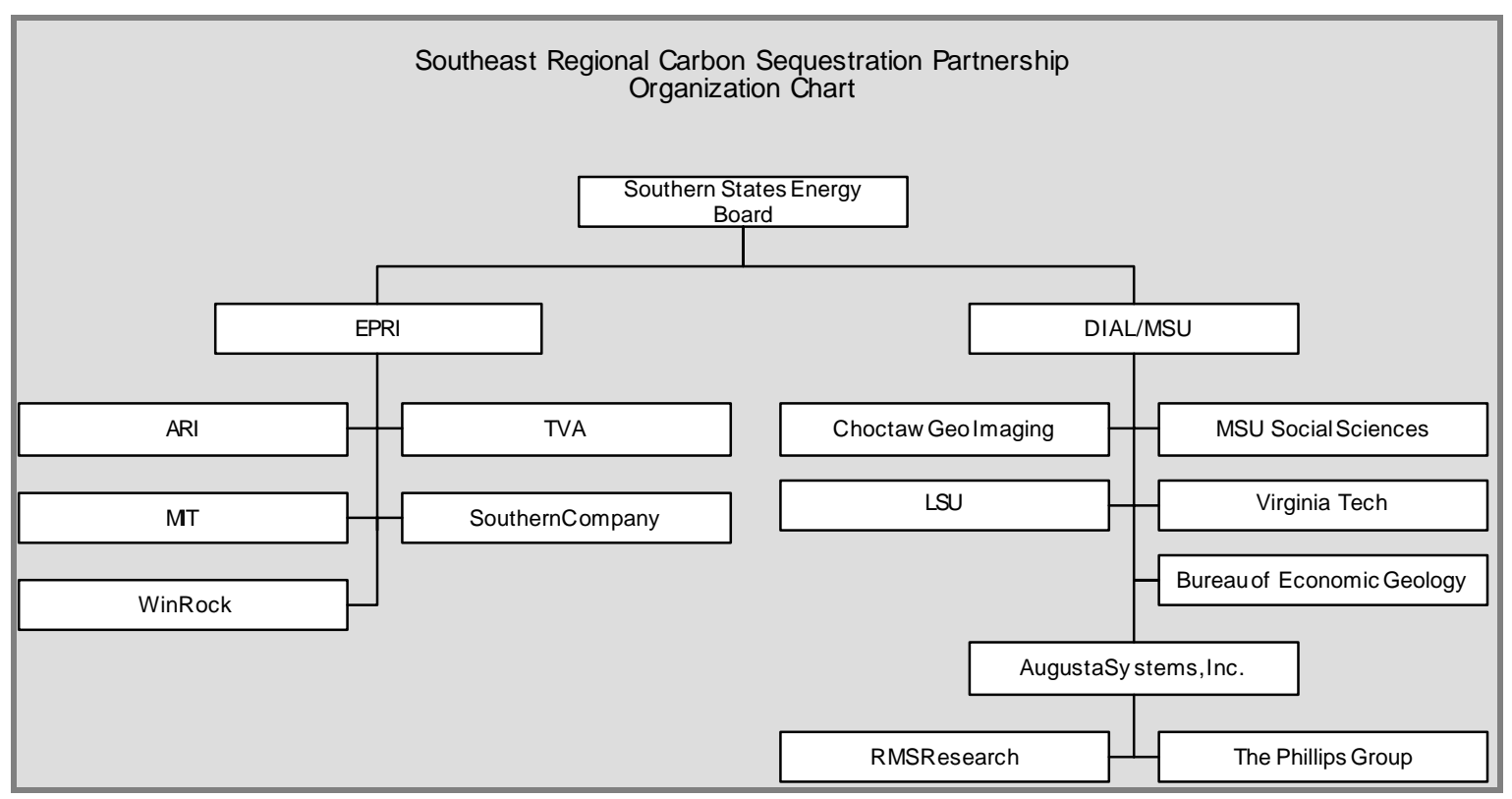

Figure 1 - Southeast Regional Carbon Sequestration Project Team Structure

The eleven states comprising the multi-state region are: 1) Alabama; 2) Arkansas; 3) Florida; 4) Georgia; 5) Louisiana; 6) Mississippi; 7) North Carolina; 8) South Carolina; 9) Tennessee; 10) Texas; and 11) Virginia. The states making up the SECARB area are illustrated in Figure 3. 


\section{Partnership “Technology Coalition”}

- AGL Resources

- American Electric Power

- Arkansas Oil and Gas Commission

- BP America

- Center for Energy and Economic Development

- ChevronTexaco Corporation

- Clean Energy Systems, Inc.

- Dominion

- Duke Power

- Edison Electric Institute Entergy Services

- Florida Power \& Light Company

- Geological Survey of Alabama

- Georgia Environmental Facilities Authority

- Georgia Forestry Commission

- Gulf Coast \& Carbon Center University of Texas at Austin
- Interstate Oil and Gas Compact Commission

- Louisiana Department of Environmental Quality

- North American Coal Corporation, The

- North Carolina State Energy Office

- Nuclear Energy Institute

- Oak Ridge National Laboratory

- Old Dominion Electric Cooperative

- Progress Energy

- SCANA Corporation

- South Carolina Public Service Authority/Santee Cooper

- Southern Company

- Tampa Electric Company

- Tennessee Valley Authority (TVA)

Figure 2 - The Partnership's Technology Coaltion Participants

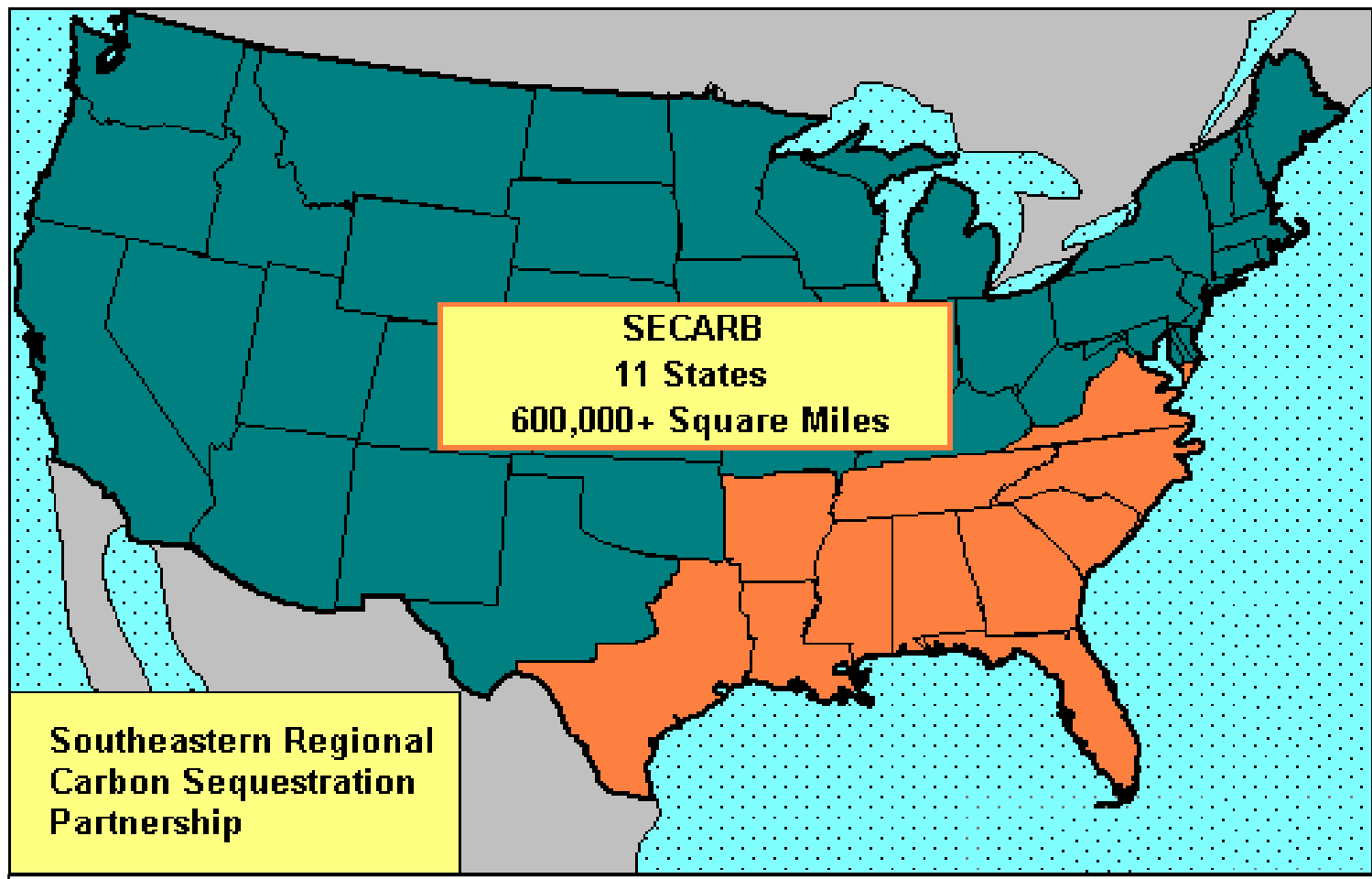

Figure 3 - States in the Southeast Regional Carbon Sequestration Partnership 


\subsection{Objectives}

The primary objectives of the SECARB project include:

(1) Supporting the U.S. Department of Energy (DOE) Carbon Sequestration Program by promoting the development of a framework and infrastructure necessary for the validation and deployment of carbon sequestration technologies. This requires the development of relevant data to reduce the uncertainties and risks that are barriers to sequestration, especially for geologic storage in the SECARB region. Information and knowledge are the keys to establishing a regional carbon dioxide $\left(\mathrm{CO}_{2}\right)$ storage industry with public acceptance.

(2) Supporting the President's Global Climate Change Initiative with the goal of reducing greenhouse gas intensity by 18 percent by 2012. A corollary to the first objective, this objective requires the development of a broad awareness across government, industry, and the general public of sequestration issues and establishment of the technological and legal frameworks necessary to achieve the President's goal. The information developed by the SECARB team will play a vital role in achieving the President's goal for the southeastern region of the United States.

(3) Evaluating options and potential opportunities for regional $\mathrm{CO}_{2}$ sequestration. This requires characterization of the region regarding the presence and location of sources of greenhouse gases (GHGs), primarily $\mathrm{CO}_{2}$, the presence and location of potential carbon sinks and geological parameters, geographical features and environmental concerns, demographics, state and interstate regulations, and existing infrastructure.

\subsection{The SECARB Approach}

SECARB developed a framework and strategy necessary for the validation and deployment of carbon sequestration technologies. This approach addressed these factors:

- $\mathrm{CO}_{2}$ storage and capture;

- $\mathrm{CO}_{2}$ transport;

- regulations;

- permitting;

- communication and outreach;

- public acceptance;

- monitoring and verification; and

- environmental efficacy of sequestration within the Southeast.

SECARB first characterized the region with respect to where the potential sinks were generally located and then focused on areas that appeared to have the best potential for matching to $\mathrm{CO}_{2}$ sources.

The initial step was a macro-level, dimensional, geographic identification of areas and particular terrestrial systems and geologic formations with sequestration potential. Terrestrial assessments focused on vegetative cover and carbon sequestration potential. 
The main types of geologic sinks considered for sequestration were saline formations, coal seams, and oil and gas reservoirs.

Subsequent steps continued the assessment initiated and refined the information, addressing data availability and quality with respect to potential sequestration targets. The data continued to be gathered, refined, and synthesized in an attempt to acquire the most-relevant datasets possible. The data was incorporated into a geographical information system (GIS) database for use in identification of priority areas for conducting Phase II activities, specifically to identify the best combination(s) of $\mathrm{CO}_{2}$ sources, sinks, and site attributes for developing sequestration field verifications.

Based primarily on data from the Texas Bureau of Economic Geology (BEG) and state geological surveys, Figure 4 ranks areas within the region according to the viability of brine formations as potential carbon sinks. The green areas show where the best prospects are located for $\mathrm{CO}_{2}$ storage in the brine formations, while the orange and red areas are indicative of where brine formations are either not present or have other problems making them marginal or high-risk prospects. The blue outlined areas on the map are where additional studies of the brine formations are needed to fully characterize their potential as carbon sinks. It should be noted that some of the green areas coincide with oil and gas producing formations, especially those adjacent to the Gulf of Mexico, providing opportunities for enhanced oil recovery (EOR) in conjunction with sequestration efforts.

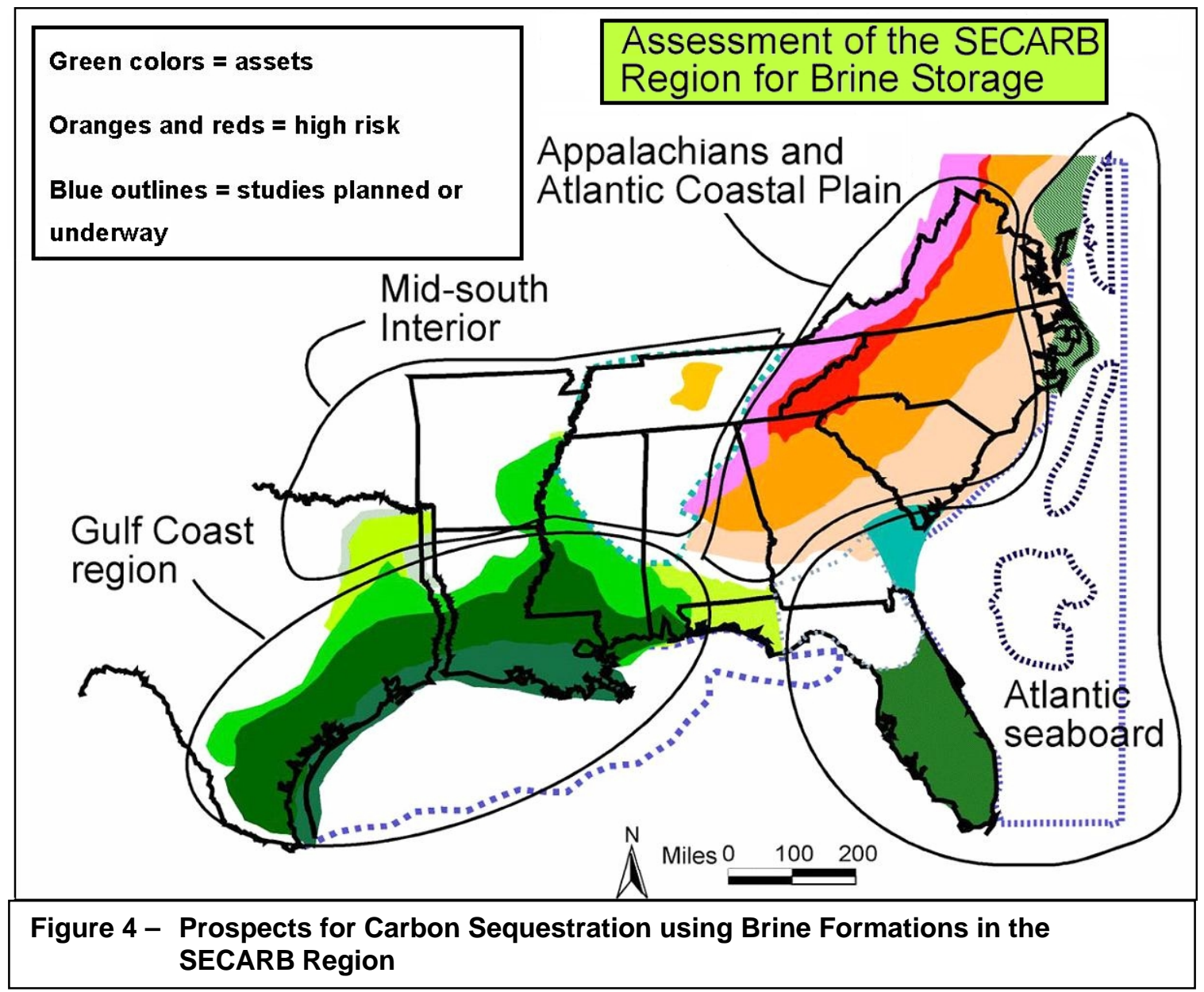


Primary data sources for the initial phase of geologic characterization included the U.S. Geological Survey's (USGS) Assessment of National Oil and Gas Resources publications (1995 and 2001), supplemented by data from DOE's Gas Information System database (Version 2, 1999); reports from the USGS's National Coal Resource Assessment; and publications obtained from the Texas Bureau of Economic Geology, Geological Survey of Alabama, the Virginia Center for Coal and Energy Research and the Massachusetts Institute of Technology. Additionally, detailed information was collected from various state geological surveys and other cognizant state agencies.

\subsubsection{Saline Formations}

Sequestration of $\mathrm{CO}_{2}$ emissions in deep, brine-bearing formations is an attractive option because large-volume sinks often can be found at depths suitable for injection and in close proximity with anthropological sources of the gas. The primary depth requirement for the brine formation is that it should be deeper than, and isolated from, fresh-water supplies. A desirable characteristic of the brine formation is that it be at a depth where the temperature and pressure conditions are such that carbon dioxide will be in a dense phase, probably supercritical.

The Texas BEG inventoried 21 suitable U.S. brine formations to provide basic data for assessing feasibility, costs, and risks of sequestration. Several of these formations were found within the bounds of the SECARB study region; thus the BEG database, augmented by information from the Geological Survey of Alabama was very useful in characterization of the region's saline formations.

\subsubsection{Coal Formations}

Because of the different mechanism for storing $\mathrm{CO}_{2}$ in coal seams (i.e., by adsorption on the surface of the coal), the depth requirement is not as significant as it is for oil, gas, or brine formations, but the target seam still should be isolated from fresh-water supplies. The main requirement for coal seams is that it should not be a minable seam. If the seam were to be mined subsequent to sequestering $\mathrm{CO}_{2}$ in the seam, most of the $\mathrm{CO}_{2}$ would be released back to the atmosphere. The $\mathrm{CO}_{2}$ also would impact mining operations and safety because the $\mathrm{CO}_{2}$, being denser than either air or methane, tends to collect in low places in the mine creating a potentially deadly safety hazard.

Data for characterizing the region's coal seams came from a variety of sources including the USGS's National Coal Resource Assessment Program, which provided well point and outcrop data on various coal seams; USDOE data sets; and data that were collected by the various cognizant state surveys.

\subsubsection{Oil and Gas Formations}

Production of oil or natural gas is rejuvenated by pumping $\mathrm{CO}_{2}$ gas into a depleted reservoir thereby providing the energy to push the product through the reservoir to production wells where it is then recovered. In an enhanced oil recovery application, some or even most of the $\mathrm{CO}_{2}$ can remain in the reservoir for permanent storage. The integrity of the $\mathrm{CO}_{2}$ that remains in the reservoir is well-understood and very high as long as the original pressure of the reservoir is not exceeded. 
Primary oil production in the United States has been declining for several years with enhanced recovery technologies helping to stem the rate of decline. The oil industry purchases about $30+$ million tons of $\mathrm{CO}_{2}$ every year to use in $\mathrm{CO}_{2}$-enhanced recovery. The scope of this EOR application currently is economically limited to point sources of $\mathrm{CO}_{2}$ emissions that are near an oil or natural gas reservoir.

Data for characterizing the region's oil and gas formations came from a number of difference sources, primarily the USGS's National Oil and Gas Assessment activity. Information also was obtained from digital information reports by the DOE such as the Gas Information Systems (GASIS). Additional information and data analysis were provided by BEG and by state geological surveys.

\section{$2.0 \mathrm{CO}_{2}$ SEQUESTRATION OPPORTUNITIES}

GIS maps showing key formations and characteristics with overlays of $\mathrm{CO}_{2}$ sources have been prepared to evaluate potential geologic sequestration options. Infrastructure layers are utilized to identify possible problems such as pipeline rerouting requirements; terrain considerations; road, railroad, or river crossings; and environmental considerations. All of these factors can impact the evaluation. Upon narrowing the sequestration options to a priority group, these prospects were pursued further to obtain specific information in order to complete the evaluation of those options. If sufficient information is not available for a given option, then that option would not be considered unless extraordinary efforts to obtain the information are warranted (e.g., drilling a test well).

\subsection{Brine Formations}

Information collected to date indicates that saline reservoirs are distributed widely throughout the SECARB region and will have the highest potential to store captured $\mathrm{CO}_{2}$. Many of these saline reservoirs are co-located with oil reservoirs. However, outside the Gulf Coast region, areas of poor data coverage exist, especially in the eastern coastal areas, resulting in gaps in information (see Figure 5).

In Phase I, SECARB has compiled information on the relative storage capacities of potential saline reservoirs in the region. Within the states evaluated, the lower Gulf Coast states including Texas, Louisiana, and Alabama, have the most extensive and thickest sedimentary sections with stacked reservoirs. Central Appalachian states have significantly less opportunities due to the amount of basement rock exposed and lack of significant sections of sedimentary thickness.

Some of the better-characterized formations within the region are the Arbuckle, Eutaw, Frio, Granite, Jasper, Lagarto, Oakville, Paluxy, and Pottsville. Other important formations with potential include the Woodbine, Wilcox, Tuscaloosa, Rodessa, Tokio, Strawn, Sunniland, Smackover, San Andres, Pettit, Oriskany, Norphlet, Navarro, Morrow, Hosston, Grayburg, Glen Rose, Ellenburger, Delaware Mountain, Cotton Valley, Canyon, Canyon Peak, and several others. 


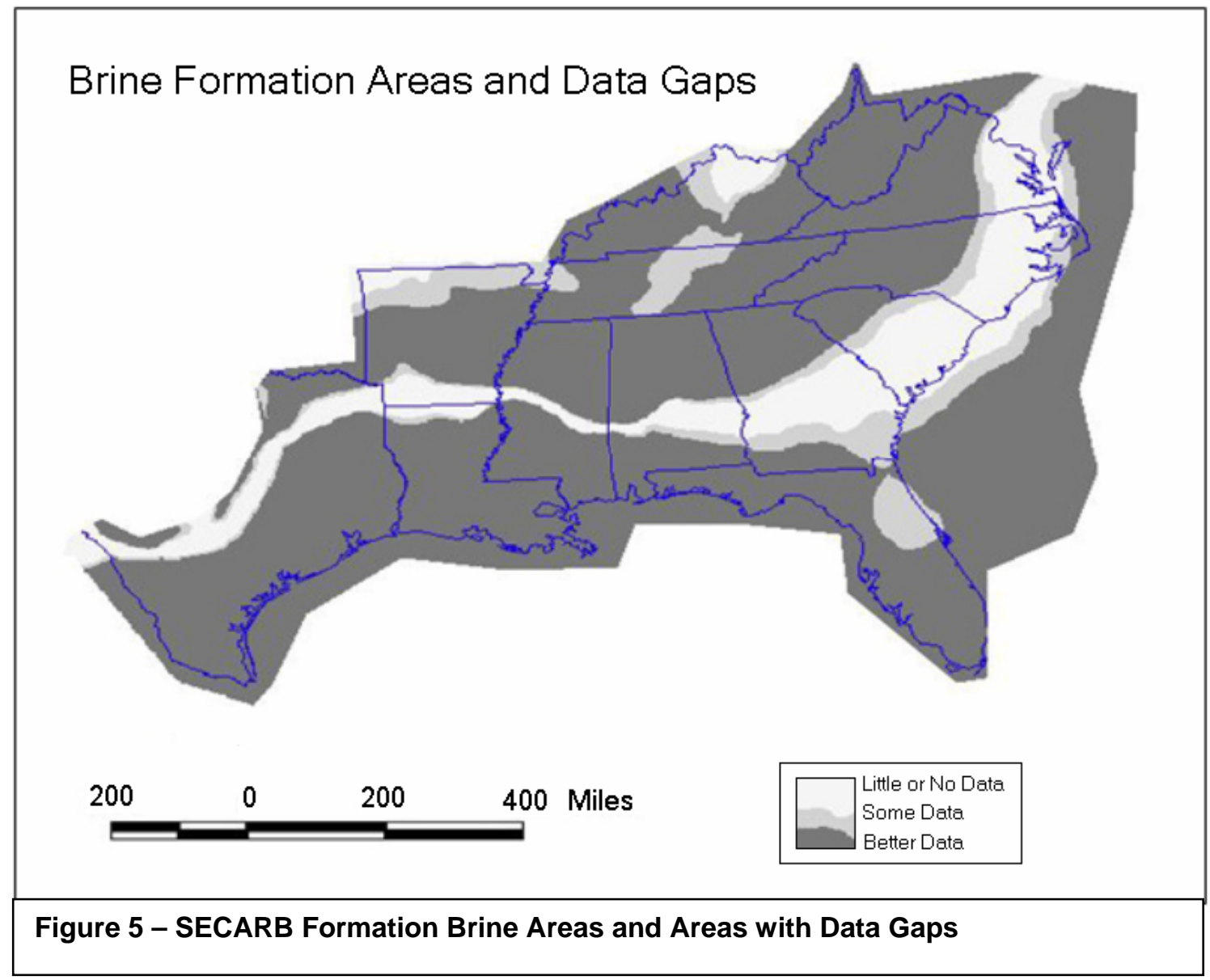

\subsection{Coal Formations}

The primary coal formations are most likely those unminable coals in areas near to where the coals have been, or are being mined because there is typically more information is available on the coals in those areas. For this reason, the Black Warrior Basin of Alabama and the Central Appalachian Basin in Virginia, West Virginia, and Kentucky have slight advantages over some of the other coals areas. Figure 6 shows the large coal areas within the SECARB Region. 
Reservoir properties of these coal seams vary significantly across the SECARB region, but each basin has large areas of unmineable coal seams with carbon sequestration potential. Variables controlling the production of coalbed methane are essentially the same as those determining carbon sequestration potential. These variables include structural geology, hydrodynamics, coal rank, gas content, and sorption capacity.

Coal rank varies from anthracite and bituminous rank coals in the Central Appalachia Basin to the lignite rank coals in East Texas. Higher gas contents are concentrated in mature coalbed methane (CBM) reservoirs in the Black Warrior Basin of Alabama and the Central Appalachian Basin in Virginia. These mature reservoirs have the greatest potential for enhanced CBM recovery because they have favorable reservoir properties, infrastructure in place, and higher recovery factors.

Some of the coals with potential for sequestration include Pocahontas Nos. 3 \& 4, Lower Horsepen, War Creek, Lower Seaboard, Jawbone, Gould, Harkness, Wadsworth, Coke, Gholson, Thompson, Montavello, and Maylene seams in the Central Appalachian Basin and the Black Creek, MaryLee, Pratt, Cobb, and Gwin coal groups in the Black Warrior Basin.

\subsection{Oil and Gas Formations}

\section{SECARB Coal Areas}

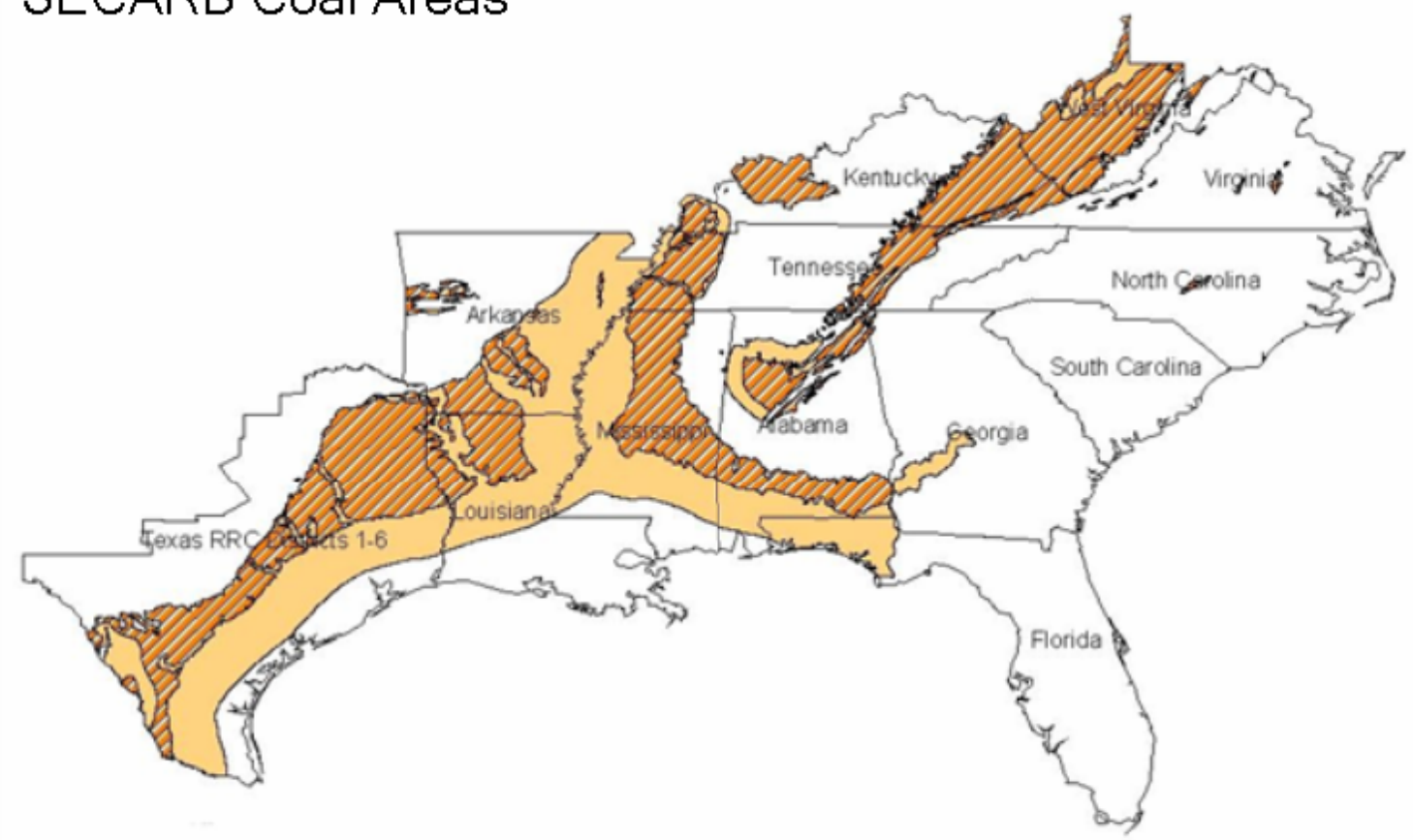

Coal Fields

Unminable

UMinable and Unminable

Figure 6 - Coal Areas within the SECARB Region. 
The number of oil and gas formations with potential for carbon sequestration is very large, but the most likely immediate candidates are where oil reservoirs are found that are acceptable for enhanced oil recovery.

Opportunities for oil and gas reservoirs are mainly available in the southwestern portion of the region, especially in Texas, Louisiana, Mississippi, and Alabama. Figure 7 shows sources, sinks, and the capacities of each for Texas, Louisiana, and Mississippi. Where feasible, $\mathrm{CO}_{2}$-EOR can provide significant revenue streams to offset the costs of transportation infrastructure, and under the right circumstances some costs associated with capture. SECARB has identified a large number of reservoirs in the Gulf Coast area as well as in Arkansas that could benefit from $\mathrm{CO}_{2}$-EOR. Many operators in the region now recognize this technique as one of the best options for sustaining production in onshore fields in the future.

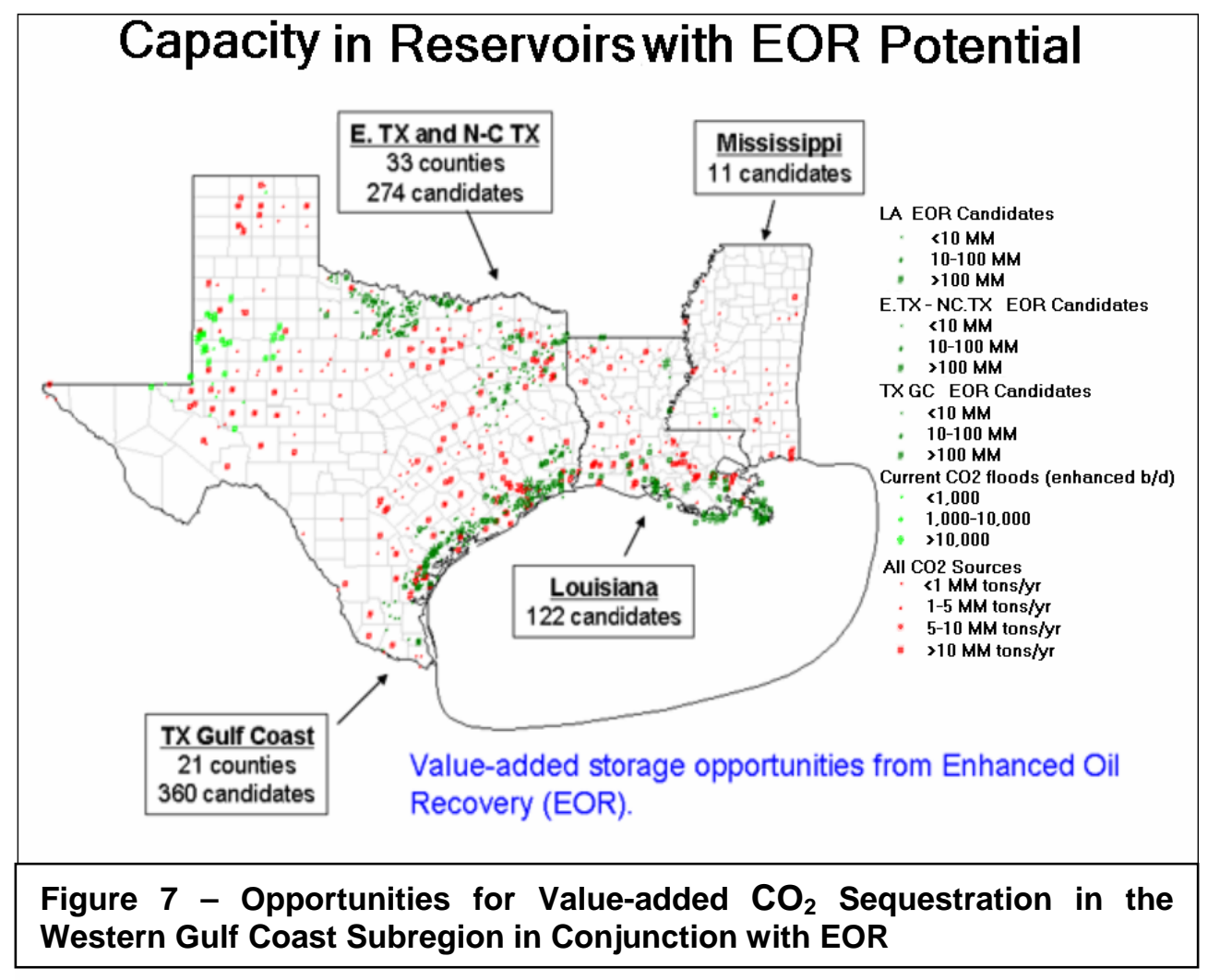

\subsection{Sequestration Targets}

In the northeastern area of the region (Virginia, North Carolina, Tennessee, and portions of Kentucky and West Virginia), the primary targets for sequestration will be unminable coal seams and brine formations.

In the southeastern area of the region (South Carolina, Georgia, and Florida), minimal opportunities exist for sequestration. However, the South Florida Basin has a large potential for $\mathrm{CO}_{2}$ storage in brine formations, especially in the Lower Cretaceous rocks 
that include the Dollar Bay and Sunniland formations, which also have potential for enhanced oil recovery. The South Florida Basin contains a thick column of sediments with porous and permeable zones separated by impermeable anhydrites.

In the central and western parts of the region (Alabama, Mississippi, Louisiana, Texas, and Arkansas) sequestration target options include coal, oil, gas, and brine formations.

\subsection{MOST PROMISING AREAS OF OPPORTUNITY}

Upon completion of the evaluation process, additional data was developed for "projects of opportunity," or source-sink combinations, and the potential projects were evaluated to determine which ones would provide good returns on investment. These project evaluations were based on cost terms of the techniques tested, research goals and questions to be answered, and their overall benefit to the sequestration effort.

SECARB completed its initial screening of potential sources and sinks for carbon sequestration, finding that potential sources of carbon dioxide emissions are located throughout the region, with large coal-fired power plants being the most prominent emitters. Also, the findings demonstrated that the region has numerous and diverse terrestrial and geologic sinks that could serve as the most promising sinks for sequestering $\mathrm{CO}_{2}$.

SECARB's action plans focus on the most promising opportunities for geologic sequestration within the region that promote the development of a framework and infrastructure necessary for the validation and deployment of carbon sequestration technologies. The action plans refine Phase I concepts and begin to validate sequestration technologies and corresponding infrastructure approaches related to regulatory, permitting, and outreach. The multi-partner collaborations developed during Phase I will continue in Phase II.

SECARB's initial areas of opportunity revolve around three focus areas: 1) a Gulf Coast focus investigating a stacked sequence of hydrocarbon and brine reservoir intervals, where enhanced oil recovery with $\mathrm{CO}_{2}$ can serve as an economic driver in establishing the $\mathrm{CO}_{2}$ infrastructure, and building on the Gulf Coast Carbon Center's (GCCC's) experience on the Frio Basin Project; 2) a Coal Seam focus for validation of sequestration opportunities in the Central Appalachian Basin and the Black Warrior Basin, where $\mathrm{CO}_{2}$ enhanced coal bed methane (ECBM) recovery operations can add economic value and where unminable coals can provide sequestration opportunities; and 3) a Saline Aquifer focus that looks at validating geologic storage in close proximity to a Southern Company coal-fired power plant that is part of the Electric Power Research Institute's Test Center program located in the Mississippi Salt Basin and separated from the Gulf Coast Salt Basin by the Wiggins Arch. (Note: Areas (1) and (3) are in distinctly different saline sinks.)

\subsection{Gulf Coast Focus - Stacked Storage}

Beneficial Use of $\mathrm{CO}_{2}$ for EOR: Anthropogenic $\mathrm{CO}_{2}$ in the SECARB region can be used for $\mathrm{CO}_{2}$-EOR. Where feasible, $\mathrm{CO}_{2}$-EOR can provide significant revenue streams to offset the costs of transportation infrastructure. Through our on-going reservoir 
screening assessment, SECARB has identified a large number of reservoirs in the Gulf Coast of Texas, Louisiana, Mississippi, Alabama, Arkansas and Florida that could benefit from $\mathrm{CO}_{2}$-EOR. Many operators in the region now recognize this technique as one of the best options for sustaining production in onshore fields in the future.

A thick sedimentary wedge of Tertiary and Quaternary rocks up to $12,000 \mathrm{ft}(3,700 \mathrm{~m})$ defines the Gulf Coast subregion, the onshore area which is $155,000 \mathrm{mi}^{2}\left(400,000 \mathrm{~km}^{2}\right)$. Internal structure and properties of the Gulf Coast wedge are well known because of extensive exploration for production of hydrocarbons. Examination of regional maps and cross-section sets (Dodge and Posey, 1981; Galloway, 1982; Hosman, 1996) shows the maximum depth (where detailed regional data are available) is $14,000 \mathrm{ft}(4,000 \mathrm{~m})$; deeper potential exists but was not assessed. Fresh and brackish water protected as underground sources of drinking water (USDW) extends relatively deep (2,000 to 3,500 $\mathrm{ft}$ [600 to $1100 \mathrm{~m}]$ ) in this region (Arthur and Taylor, 1990; LBG Guyton Associates, 2003, Brackish groundwater manual for Texas; Hovorka and others, 2004). In order to give adequate protection to USDW, the SECARB team assumes potential storage will begin at $4,000 \mathrm{ft}(1,200 \mathrm{~m})$, which will allow the injection zone to be overlain by several thick, extensive shale-seal barriers to migration and a buffer of permeable sandstones to assure high permanence of storage. Sandstone porosity and permeability are high in the relatively young sediments of the Gulf Coast wedge, averaging 25 percent to 35 percent and 0.5 to 3 darcys. With respect to the national picture, the entire region is a target, so an average net sand value of 23 percent was used, based upon the evaluation of type logs (Dodge and Posey, 1981). Using the lower Gulf Coast area of $240,000 \mathrm{~km}^{2}$ with a stratigraphic thickness of 2,400m (2.4 km), 23 percent net sand, and 32 percent porosity, GCCC calculated total brine-filled subsurface porosity capacity of $42,000 \mathrm{~km}^{3}$. Injection simulation in typical, geologically heterogeneous Gulf Coast sandstones (Hovorka and others, 2004) has shown that capacity is a complex calculation of multiple variables, including dissolution, two-phase trapping, buoyancy trapping, and complex migration paths. Therefore, these simplistic calculations of capacity to store $\mathrm{CO}_{2}$ represent a maximum value and may overstate the potential storage. Additional experimentation followed by modeling is needed for realistic and defensible capacity assessment to be done; thus, the SECARB team will attempt to assess some of the critical unknowns. On the other hand, just 1 percent of the large subsurface volume would hold 428 years of the region's entire current $\mathrm{CO}_{2}$ production, which motivates continued research.

Total emissions for the subregion calculated from Hendricks and others (2002) are $0.3 \times$ 109 tonnes $\mathrm{CO}_{2}$, which represents 25 percent of U.S. emissions. Refineries and chemical plants contribute to this $\mathrm{CO}_{2}$, which is significant because about 17 percent of these emissions are from high-concentration sources at hydrogen reformers and ethylene oxide plants. Use of these existing concentrated sources can help initiate storage opportunities before implementation of large-scale capture, avoiding this barrier to rapid implementation. Half the generating capacity of the subregion is from coal- and lignite-fired power plants; the other half is gas-fired, providing a diverse suite of options for capture. Both refiners (ChevronTexaco and BPAmoco) and utilities (Entergy and NRG) have joined the GCCC and are engaged actively in seeking a viable carbon capture and storage project (CCS) in a geologic setting with an economic driver. Without an effective program to capture and store $\mathrm{CO}_{2}$ emissions from the Gulf Coast, the national GHG intensity goals become more difficult to reach.

The Gulf Coast pilot is focused upon defining injection and monitoring, measurement 
and verification (MMV) criteria for stacked reservoirs with oil and brine intervals for the storage of anthropogenic $\mathrm{CO}_{2} \mathrm{GHG}$. The value of evaluating stacked reservoirs is that $\mathrm{CO}_{2}$ used for EOR has a market value that can help drive the development of a pipeline infrastructure in the Gulf Coast region for delivering large volumes of $\mathrm{CO}_{2}$ for long-term geologic storage, thus reducing the negative effects of $\mathrm{CO}_{2}$ in the atmosphere.

Enhanced oil recovery using $\mathrm{CO}_{2}$ could generate significant potential revenue streams to offset or completely cover costs of transportation infrastructure. Stakeholders, $\mathrm{CO}_{2}$ emitters, operators, and communities, have shown strong interest in taking action to prolong production at fields with declining production through $\mathrm{CO}_{2}$-EOR. Over the last year, GCCC, through SECARB collaboration and academic funding, has completed an assessment of geologic storage options in the Gulf Coast region.

This work inventoried 0.4 billion tons of $\mathrm{CO}_{2}$ produced annually from 316 stationary sources in the region. Capture of $\mathrm{CO}_{2}$ from these sources could supply a $680-\mathrm{mi}(1,095-$ $\mathrm{km})$ pipeline infrastructure that links the Gulf Coast region in a network extending from Alabama to Mexico. This area comprises 767 oil and natural gas reservoirs that could be used first for EOR and then for large-volume, long-term storage of $\mathrm{CO}_{2}$ in nonproductive formations below the reservoir interval. Modest investments could provide economic incentives for the oil and gas industry to support expanded EOR programs that will yield potential storage sites. Within Texas alone, outside the traditional area of $\mathrm{CO}_{2}$-EOR in the Permian Basin, an additional estimated 5.7 billion barrels (Bbbl) of oil could be produced by using $\mathrm{CO}_{2}$-EOR. By way of comparison, annual U.S. oil production is currently $3.2 \mathrm{Bbbl}$. At $\$ 30$ per barrel, the $5.7 \mathrm{Bbbl}$ of incremental production is estimated to have a wellhead value of $\$ 171$ billion, generate $\$ 26$ billion in taxes, and result in $\$ 498$ billion of economic activity. This EOR activity also could lead to the storage of more than 700 million tons ( 0.7 gigaton) of $\mathrm{CO}_{2}$-only a small part of the positive impact. The true prize will be that EOR could enable construction of a $\mathrm{CO}_{2}$ pipeline infrastructure that could allow cost-effective storage of a Gulf Coast power plant, refinery, and chemical plant emissions from fossil fuel combustion for the next 50 years or more.

Many large-volume, well-characterized geologic $\mathrm{CO}_{2}$ storage targets lie along the Gulf Coast in a stacked sequence of hydrocarbon and brine reservoir intervals. Hydrocarbon reservoirs and brine formations provide highly-injectable (high-permeability, -porosity) zones that underlie diverse, high-volume $\mathrm{CO}_{2}$ point-source emitters. This area seeks to reduce uncertainties and risks that are barriers to geologic storage; and develop a regional $\mathrm{CO}_{2}$ storage industry with public acceptance. Key research issues include injected $\mathrm{CO}_{2}$ interaction with faults; pressure distribution during and after injection; injection impact on regional fluid flow and poro-elastic deformation; and near-surface $\mathrm{CO}_{2}$ monitoring in wetlands. This area has the potential to implement capture and geologic storage owing to concentration of diverse $\mathrm{CO}_{2}$ sources (heavy industry, coalfired power plants); high level of public, regulator and stakeholder comfort with underground injection (extensive experience with Class I and II wells); and economic, public, and policy-maker support because of $\mathrm{CO}_{2}$ potential for enhanced oil recovery as an economic driver to finance pipeline infrastructure that could enable large-scale sequestration of $\mathrm{CO}_{2}$ from coal-fired power plants. This area could test a model for early injection into an oil reservoir, followed by long-term, large-volume storage in underlying brine formations.

The Phase II goal is validating the $\mathrm{CO}_{2}$ distribution model during and after injection, as 
well as accurate assessment of stratigraphic interval being impacted. Thus, key research issues include injected $\mathrm{CO}_{2}$ interaction with faults; pressure distribution during and after injection; injection impact on regional fluid flow and poro-elastic deformation; and nearsurface $\mathrm{CO}_{2}$ monitoring in wetlands. All these aspects will lead to a more accurate prediction of $\mathrm{CO}_{2}$ storage capabilities and risks, which will assist the public and private sectors in determining that geologic storage of anthropogenically generated $\mathrm{CO}_{2}$ is a safe and economic process for reducing this greenhouse gas.

\subsubsection{Suitability}

The Gulf Coast, and more specifically the states of Alabama, Florida, Louisiana, Mississippi, and Texas, is a prime target area for geologic storage. This area is particularly attractive because:

- high-capacity sinks are widely available with excellent injectivity properties;

- regional $\mathrm{CO}_{2}$ emissions from coal-fired power plants and other large point sources are high;

- economic drivers for developing a $\mathrm{CO}_{2}$ capture and pipeline infrastructure are rapidly evolving;

- vast data sets exist that characterize structure and reservoir properties of the thick section of high-porosity, high-permeability sands of the Gulf Coast;

- an infrastructure of pipelines and pipeline rights-of-way exist; and

- both permitting experience and public acceptance exist.

Collectively, these factors are consistent with the Gulf Coast becoming the "Low Cost Provider" for an evolving U.S. sequestration industry, which can help the United States reach national emissions reduction targets in the future.

To position the SECARB region to take advantage of these considerable assets, this focus proposes to explore scientific and engineering issues to enable successful implementation of the stacked storage model. Stacked storage means that $\mathrm{CO}_{2}$ will be injected into an oil reservoir (to provide the economic incentive necessary to build the required capture, compression, and pipeline infrastructure) and in large volumes into underlying brine-saturated sandstones. $\mathrm{CO}_{2}$ injection-based EOR thus provides the incentive and capital to start the sequestration process. Working with an oilfield operator is the only way to obtain a significant volume of $\mathrm{CO}_{2}$ storage that will support the needed experiment. Currently in the Gulf Coast, $\mathrm{CO}_{2}$ is a food commodity selling at $\$ 100+$ a ton, compared with natural pipeline $\mathrm{CO}_{2}$ in the Permian Basin of Texas currently selling at $\$ 12$ to $\$ 17$ a ton.

Large-volume storage in brines beneath reservoirs provides sites with high probability for minimal leakage rates and effective permanence for storage of emissions from coal-fired power plants and other point sources. SECARB will use the available infrastructure (wells, roads), characterization (wireline logs, seismic), ease of permitting and public acceptance provided by the EOR operation to support planning and initial injection into a deeper brine formation. Over the long term, storage in formations below hydrocarbonproducing formations provides a high assurance of permanence because: 
- the characteristics are already relatively well known via seismic, reservoir characterization, and exploration for deeper targets;

- well penetrations (potential leak points) are sparse relative to the reservoir; and

- any $\mathrm{CO}_{2}$ in the oil reservoirs has excellent expectations for storage permanence (because the reservoirs have demonstrated seals and sorption by residual oil, providing a secondary trap).

The stacked storage model has significance for the entire U.S. sequestration program by:

- pioneering permitting processes for $\mathrm{CO}_{2}$ disposal;

- reducing performance assessment uncertainty issues, such as the nature of interaction of $\mathrm{CO}_{2}$ injection with faults;

- distributing pressure in the near and far field during and after injection (and its impact on fluid flow and deformation); and

- developing an aggressive and successful plan to capture and store a significant proportion of the subregion's emissions (and even offset emissions from subregions where subsurface environments are more limited).

\subsubsection{Site Availability}

SECARB has selected 15 fields where the designed field test could be conducted successfully and where operators have expressed interest in hosting the test. SECARB will work with potential site operators to determine whether the project could be economically successful and whether the proposed storage research can be conducted successfully at the site. The potential fields have moderate to steep dips typical of Gulf Coast reservoirs and updip fault seals. The operator will provide an injection well, either a retrofit of an exiting well or a new well, and workover as needed of producing wells that will be within the oil bank and area of eventual $\mathrm{CO}_{2}$ recycling. The SECARB team will reduce risks to the operator by supporting initial months of purchase of $\mathrm{CO}_{2}$. The injection interval will be a typical high-porosity, high-permeability sandstone with shale seals; the underlying brine target will be lithologically similar.

\subsubsection{Permitting Requirements}

The process of permitting injection wells through the U.S. Environmental Protection Agency's (EPA) Underground Injection Control (UIC) program is well known and has been used extensively in the Gulf Coast states. Relevant permit types are Class I nonhazardous disposal wells, Class II enhanced recovery wells, and Class V experimental wells. Each state has primacy (state agencies handle permitting under state rules, except for Florida Class II) and experience with permitting UIC wells. Texas has 110 Class I nonhazardous wells and 53,000 Class II wells; Florida has 112 Class I nonhazardous wells; and Louisiana, Mississippi and Alabama all have experience in permitting agencies that can provide guidance to the U.S. $\mathrm{CO}_{2}$ storage program as it matures.

In all permit types, the basic process remains the same: 
- geologic characterization to define underground sources of drinking water;

- demonstration of the seal integrity and well penetrations in the area of review;

- calculation of the injectivity (permeability $\times$ thickness) of the injection zone, which will define maximum allowable surface injection pressure (MASIP) and permitted injection volume;

- preparation of engineering drawings of proposed well completion and surface facility design;

- submission of required documentation to appropriate state agencies and other parties;

- response to agency and stakeholder comment;

- review of as-built specifications to obtain permission to proceed; and

- record-keeping and reporting.

The proposed stacked storage model will require two state permits:

- a Class II permit for the $\mathrm{CO}_{2}$-EOR process; and

- a disposal well permit.

SECARB will work with state and federal regulators, DOE, and with advisors in nongovernmental organizations (NGO) to determine necessity for a Class I nonhazardous permit, Class $\vee$ experimental permit, or a new classification for $\mathrm{CO}_{2}$.

A significant goal of this experiment is to advance confidence in the permitting process for $\mathrm{CO}_{2}$ disposal by working the first U.S. $\mathrm{CO}_{2}$ disposal permit through the system. Because the site could be in wetlands, a state assessment of impact on wetlands may be required and the proposed project will require a National Environmental Policy Act (NEPA) assessment. Because the project will use existing surface infrastructure, these assessments should result in findings of minimal impact.

\subsection{Coal Seam Focus}

SECARB-developed data indicate that $\mathrm{CO}_{2}$-enhanced recovery can prolong the life of CBM reservoirs and may increase CBM reserves by more than 20 percent in the Black Warrior Basin. During Phase I, the project conducted extensive mapping of the coals in the Central Appalachian and Warrior basins to identify the $\mathrm{CO}_{2}$ storage capacity and favorable pilot site locations. A series of detailed cross-sections were prepared and a complete well data file was assembled for these two basins. During Phase II, more detailed characterization will be conducted to define the properties of the most favorable $\mathrm{CO}_{2}$ storage sites.

The focus is on unminable coal seams with high methane content in the coal fields extending from the Appalachian range, southwest into the Black Warrior Basin and towards the Gulf Coast. Enhanced coalbed methane recovery can serve as an economic driver to finance pipeline infrastructure.

Previous research and the ongoing characterization studies under Phase I identified two "high-graded" sites for geologic sinks in coal seams within the region. This area provides 
the opportunity to run parallel pilot tests in the Black Warrior Basin and the Central Appalachian Basin. Through the use of mature CBM production areas and available subsurface and well data, project risk can be minimized and costs contained. In addition, one field test will be a multi-lateral horizontal injection test performed in Central Appalachia that may provide a technological breakthrough in terms of carbon sequestration injection efficiencies.

Black Warrior Test Site: The Black Warrior Basin and adjacent parts of the Appalachian thrust belt comprise a geographical subregion that contains a diverse assemblage of potential carbon sinks including coal, mature oil and gas reservoirs, and saline aquifers. Among these potential sinks, coal is especially promising because of the potential to sequester large volumes of greenhouse gas while enhancing CBM production. In some Black Warrior coalbed methane fields, the $\mathrm{CO}_{2}$ storage capacity of coal locally exceeds $2 \mathrm{MMscm} / \mathrm{acre}$, and the amount of gas left in place after primary CBM recovery is estimated at more than 0.4 MMscm/acre in some areas (Pashin et al., 2004). Coal in the Black Warrior Basin may be used to sequester up to $1.2 \mathrm{Tscm}$ (42 Tcf or $0.6 \mathrm{GtC}$ ) of $\mathrm{CO}_{2}$, which is equivalent to 35 years of $\mathrm{CO}_{2}$ emissions from nearby coal-fired power plants at current rates. Through ECBM, more than $14 \mathrm{MMscm}$ (500 MMscf) of methane $\left(\mathrm{CH}_{4}\right)$ may be recoverable from the established CBM fields in the Black Warrior Basin, which could prolong the life of the CBM reservoirs substantially and result in a 20 percent expansion of CBM reserves in the basin.

Two coal-fired power plants adjacent to the Black Warrior coalbed methane fields emit more than 31 megatons of $\mathrm{CO}_{2}$ a year, and the proximity of these plants to the CBM fields makes validation of sequestration and ECBM potential a major priority. Additional capacity exists in CBM reservoirs in the Appalachian thrust belt, but this capacity has yet to be fully assessed. A third coal-fired power plant that emits nearly 14 megatons $(0.0035 \mathrm{GtC})$ of $\mathrm{CO}_{2}$ annually is located near these reservoirs, thus potential ECBM recovery in the Appalachian thrust belt of Alabama will be assessed during the Phase II program.

Central Appalachian Basin Test Site: In the region surrounding the proposed Central Appalachian pilot test area are several coal-fired electrical power generation plants that could provide a large source of $\mathrm{CO}_{2}$, which if not captured for sequestration would be discharged to the atmosphere. The coal fields surrounding the generation facilities provide abundant potential sequestration sinks for captured $\mathrm{CO}_{2}$, the extent of which will be further addressed in the SECARB project. This region of Appalachia has been densely drilled for both conventional reservoirs; therefore, an extensive and mature natural gas pipeline infrastructure exists over most of the area defined for carbon sequestration potential. This pipeline infrastructure may help to provide pipeline rightsof-way to transport $\mathrm{CO}_{2}$ from the facilities to injection locations within the coal fields.

The area identified in the Central Appalachian Basin for carbon sequestration opportunities in coal seams encompasses portions of southwestern Virginia (Buchanan, Dickenson, and Wise counties, southern West Virginia (Fayette, McDowell, Raleigh, and Wyoming counties), and counties in eastern Kentucky (Harlan, Letcher, and Pike counties). A total storage capacity of $0.86 \mathrm{Tscm}(0.44 \mathrm{GtC})$ has been estimated for the Middle to Lower Lee and Pocahontas formations in Buchanan and Dickenson counties, Virginia (Karmis, 2005). The technically feasible storage capacity estimate for these two counties, excluding minable areas and areas not yet developed for CBM production, is $0.31 \mathrm{Tscm}(0.16 \mathrm{GtC}) . \mathrm{CO}_{2}$ sequestration has the associated potential to recover an incremental $22.7 \mathrm{Bscm}$ (800 Bscf) of enhanced coalbed methane. The prospect of enhancing CBM production while proving that carbon sequestration in coal seams is 
feasible in the southeastern United States will represent significant progress in limiting GHGs in the region.

\subsubsection{Suitability}

Coal seams are among the most attractive potential $\mathrm{CO}_{2}$ sinks occurring in the southeastern United States, where a prolific CBM industry has produced more than 65 $\mathrm{Bscm}$ of the gas. Mature CBM reservoirs in the Southeast are concentrated in the Black Warrior Basin of Alabama and in the Central Appalachian Basin. These reservoirs are distinguished by numerous productive coal seams with individual thickness between 0.3 and $4 \mathrm{~m}$, distributed through 700 to $1,500 \mathrm{~m}$ of section.

Coal-fired power plants with combined annual $\mathrm{CO}_{2}$ emissions exceeding 31 megatons are immediately north of the Alabama CBM fields, and mature CBM wells are abundant in the Blue Creek Field near the plants. Safe and viable test sites are available in the Black Warrior Basin in areas that are minimally faulted; have thick, widespread coalbeds; and contain formation water with total dissolved solids content higher than $3,000 \mathrm{mg} / \mathrm{L}$ (a UIC compliance requirement). The Blue Creek Field, with large sections of the field meeting all three criteria, has been chosen as the location for the Black Warrior Basin field test on the bases of safety, logistical viability, and the ability to meet state and federal UIC requirements.

The most favorable areas delineated for the Central Appalachian sequestration pilots are located within the CBM production region in Buchanan and Dickenson counties, Virginia, and in McDowell and Wyoming counties, West Virginia. Economic production in the Central Appalachian region began in 1988 with the development of the Nora CBM field by Equitable Production Company (Equitable), located primarily in Dickenson County, Virginia. Since that time, over 3,500 CBM wells have been drilled and completed through year-end 2004 in the Central Appalachian Basin. The strata in the basin are comprised of multiple Pennsylvanian-age coal seams with composite thicknesses ranging from 4.5 to over 9 meters of net coal. The prospective coal seams are mostly low to medium volatile bituminous, have high gas contents of 5.6 to over $17 \mathrm{scm}$ per ton (200 to 600+ scf per ton), and occur at favorable depths for storage. CBM development in the area has provided extensive geological, engineering, and production data, which are available for reservoir modeling. The CBM productivity of the province indicates that coal permeabilities should be acceptable for $\mathrm{CO}_{2}$ injection, and preliminary calculations indicate approximately $0.86 \mathrm{Tscm}$ of feasible $\mathrm{CO}_{2}$ storage capacity in the two-county test area in Virginia. Favorable reservoir characteristics for coal seam carbon sequestration also exist in adjacent counties in southern West Virginia and eastern Kentucky. These counties also will be included in the regional mapping and test selection process.

\subsubsection{Site Availability}

Numerous operators, including CDX Gas, El Paso Natural Gas, Geomet Operating Company, Energen Resources, ChevronTexaco and Dominion Black Warrior, are active in the Black Warrior CBM fields near Southern Company's Gorgas and Miller coal-fired power plants. Discussions with coal field operators indicate that many candidate wells are available for testing. The Geological Survey of Alabama (GSA) is working closely with these operators to identify well sites that are viable candidates for injection-falloff testing, production testing, and monitoring. Because the geological conditions and surface logistics vary significantly among the potential test sites, it would be premature to select a final test site until after running baseline reservoir models and conducting 
surface reconnaissance of the potential sites. Beginning in Phase II, a series of candidate sites will be characterized geologically, and predictive reservoir models will be developed. The results of geological characterization and modeling will be used to select the most viable test site and to finalize the site design and monitoring plan.

The energy operators in the area of the Central Appalachian test include CONSOL Energy, Equitable Gas, CDX Gas, Penn Virginia, AMVEST Oil \& Gas, GEOMET Operating Company, and Energy Search. Work has been initiated for site access and support from industry, and the response has been very positive. Proposed injection testing in the Central Appalachian Basin is likely to be in a vertical well in Virginia and a multi-lateral horizontal well in West Virginia. CDX Gas, AMVEST Oil \& Gas, and CONSOL Energy will each contribute a well for site specific testing (the CDX well will be horizontal). Buchanan Energy Company, Equitable Gas, McJunkin Corporation, Dart Oil and Gas Corporation, and The United Company have pledged support with technical data, property access, and other support. Local citizens and communities also are informed of the potential merits of carbon sequestration in the region and are expected to support the project.

\subsubsection{Permitting Requirements}

Injection wells used for $\mathrm{CO}_{2}$-ECBM recovery are EPA Class II UIC wells, and for the Black Warrior field test, the State Oil and Gas Board of Alabama (AOGB) has primacy over the Class II program. GSA and AOGB share offices and administration, which will help facilitate the permitting process associated with this study. Common ownership of the well sites in Blue Creek field also will simplify the permitting process. Permits for $\mathrm{CO}_{2}$ injection will be obtained, and well testing and monitoring activities will commence after the final test site is chosen.

For the Central Appalachian Virginia field test, the Class II UIC permit will be obtained through EPA Region 3, since Virginia does not have primacy over that Class II program. However, obtaining the required permit should not present a problem because the field project is expected to be conducted on a large lease with the coal owners' approval for $\mathrm{CO}_{2}$ injection. For the Central Appalachian test site, permitting requirements will be similar to those in Alabama, as West Virginia also has primacy over its Class II program.

\subsection{Saline Aquifer Focus}

The saline formation opportunity centers on a Southern Company power plant where suitable geologic storage has been identified. It is located along the southern boundary of the Mississippi Interior Salt Basin above the most significant structure of the local geology, the Wiggins Arch (Figure 8), which separates the Mississippi Salt Basin from the Gulf Coast Salt Basin. The Mississippi Salt Basin subsurface in the region is characterized by numerous salt related structures such as salt domes, ridges, and anticlines, as a result of ascension of the Jurassic-age Luann Salt upon sediment loading. South of the site area, sediments dip into the Gulf of Mexico where they also are punctuated by salt pier cement domes of the Louann Salt.

Jurassic through Tertiary-age sediments in the stratigraphic section above the Paleozoic-age basement are 20,000+ feet thick. The stratigraphic section in the area thins northward and thickens southward toward the Gulf Coast, except over salt 
structures and basement structures. Regional dip is to the Southwest.

Tertiary-age lithology
consists of sand with
interbedded shale and a
minor amount of limestone.
The Cretaceous-age
lithologies consist of
interbedded sandstone, shale, and limestone with minor amounts of anhydrate. The Jurassic-age lithologies include salt, anhydrite, limestone, dolomite, and sandstone. Deep confined aquifers for the site area include sandstones of the Cretaceous-age Eutaw, Tuscaloosa, Dantzler, Paluxy, and Sligo formations and the Jurassic-age Cotton

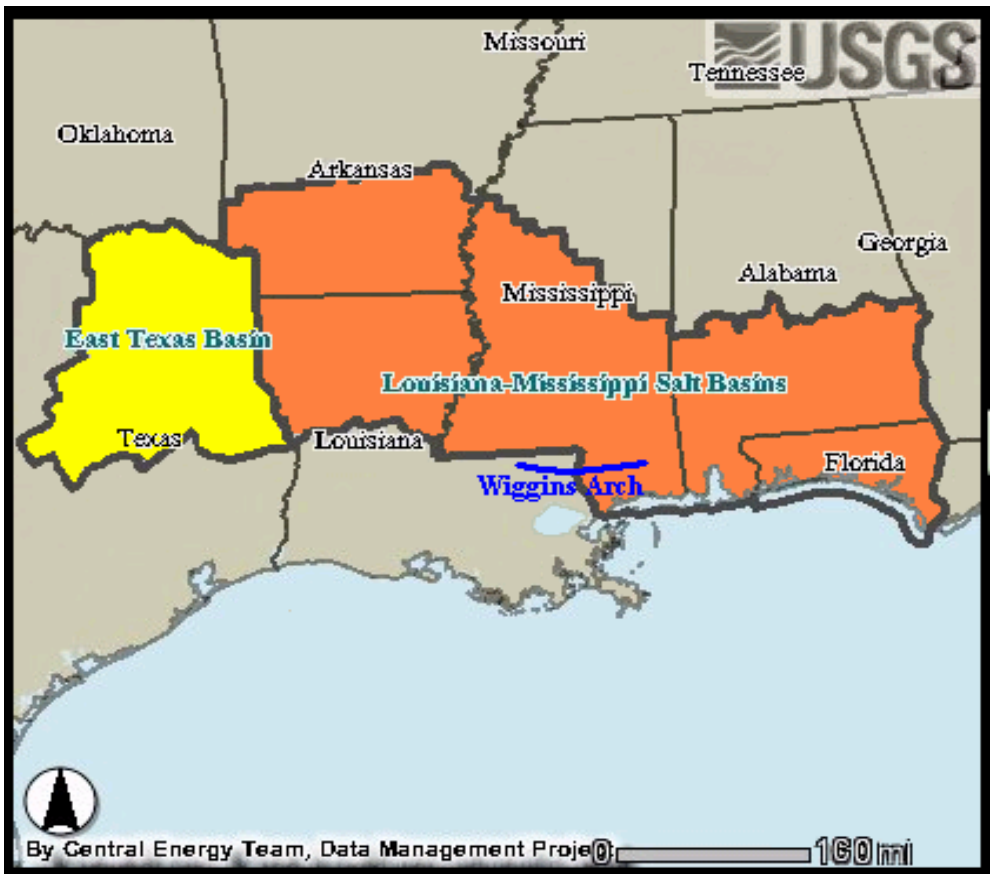

Figure 8 - Louisiana-Mississippi Salt Basins Province with Approximate Location of the Wiggins Arch

Valley and Norphlet formations. Where these sandstones are in fault blocks and truncate at the flanks of salt domes, some oil and gas may be trapped within these larger aquifer systems.

These sandstone and carbonate aquifers and their associated confining units are part of the Gulf Coast Cenozoic to Mesozoic-age mixed siliciclastic carbonate wedge that attains a maximum thickness of over 23,000 feet and extends from northern Mississippi to deep into the Gulf of Mexico. This wedge of sediments and rocks thickens northwestward from the site area into the Mississippi Interior Salt Basin, thins over the Wiggens Arch, and then thickens again into the Gulf of Mexico.

The Cretaceous-age Eutaw formation reservoir is a marine shelf sandstone found at 8,000 feet near the major salt domes in the site area. Eutaw reservoir porosities range up to 30 percent with permeabilities up to 500 millidarcies. Eutaw formation thickness is 500 feet containing 50 percent sandstone.

The Cretaceous-age Tuscaloosa and Lower Tuscaloosa, Dantzler, and Paluxy reservoirs consist of fluvio-deltaic sandstone and are found at depths of 9,000 to 11,000 feet. Reservoir porosities range up to 30 percent with permeabilities as high as 1,000 millidarcies. The combined Tuscaloosa and Lower Tucscaloosa, Dantzler, and Paluxy formations are 3,000 thick and consist of 50 percent sandstone.

The Sligo/Hosston reservoir is composed of deltaic and shelf deposits and is found at depths of 12,000 to 14,000 feet. Reservoir porosities range up to 15 percent with permeabilities up to 15 millidarcies. The combined Sligo/Hosston formation thickness is 2,500 feet, consisting of 65 percent sandstone. 
The Jurassic-age Cotton Valley formation is a deltaic to slope-fan deposit found at 15,000 feet of depth. Cotton Valley reservoir porosity ranges up to 15 percent with permeabilities up to 15 millidarcies. Cotton Valley formation thickness is 1,500 feet containing 90 percent sandstone.

The Jurassic-age Norphlet formation is an eolian deposit at a depth of 22,000 feet. Reservoir porosities range up to 12 percent with permeabilities of less than five millidarcies with a thickness of 200 feet.

$\mathrm{CO}_{2}$ sources are plentiful in the area and include ethanol plants, refineries, fertilizer plants, and gas processing plants. Denbury also is considering an extension of their $\mathrm{CO}_{2}$ transportation line to the South to pick up additional markets. This could provide the test site a back-up source of $\mathrm{CO}_{2}$ should industrial sources of $\mathrm{CO}_{2}$ not be available or too costly.

Using the reservoir attributes of Cretaceous through Jurassic-age aquifers in the site area, we calculate $550 \mathrm{Bscf}$ of $\mathrm{CO}_{2}$ storage capacity $(0.0081 \mathrm{GtC})$ per square mile of structural closure.

This area will be of sufficient scale to validate the feasibility of $\mathrm{CO}_{2}$ sequestration options in the region. The site is located in a geological setting near numerous coal-fired power plants that could support significant storage of future $\mathrm{CO}_{2}$ emissions in the region.

The project's ultimate goal is to locate suitable geologic sequestration sinks in proximity to large coal-fired power plants. The primary $\mathrm{CO}_{2}$ geological storage options for the SECARB region are the extensive saline aquifers that underlie many of the power plants in the region including the Cretaceous-age Eutaw saline aquifer in the south-central portion of the region. A successful field test in the Eutaw saline aquifer, including the design, implementation, and monitoring of this field test, will significantly help DOE's National Energy Technology Laboratory (NETL) meet the $\mathrm{CO}_{2}$ geological storage goals set forth in the Carbon Sequestration Roadmap including:

- gaining an improved understanding of the factors affecting $\mathrm{CO}_{2}$ storage performance and capacity in an important class of saline aquifers;

- demonstrating the ability to predict $\mathrm{CO}_{2}$ storage capacity within \pm 30 percent accuracy; and

- developing field practices to optimize $\mathrm{CO}_{2}$ storage.

Close integration of in-depth reservoir modeling, pilot site monitoring, and rigorous site installation design and operation will ensure that this field project will contribute to these important DOE/NETL goals.

\subsubsection{Suitability}

The primary $\mathrm{CO}_{2}$ geological storage options for the SECARB region are the extensive saline aquifers that underlie many of the power plants in the region. Work performed during Phase I shows that geologically favorable saline aquifers underlie Alabama, Florida, Louisiana, Mississippi, Tennessee, and East Texas. Future work is expected to show that favorable saline aquifers and $\mathrm{CO}_{2}$ storage potential also underlie Arkansas and portions of Georgia. The Mississippi Salt Basin project will be of sufficient scale to 
validate the feasibility of the $\mathrm{CO}_{2}$ sequestration options in this region and will be sufficiently representative of the geological and geographical settings of the region for its results to be transferable throughout the region. The project site will be in a geological setting capable of supporting significant storage of future $\mathrm{CO}_{2}$ emissions in the region.

\subsubsection{Site Availability}

The saline formation focus will be conducted at a Southern Company power plant where suitable and accessible geologic storage has been identified. The proposed geologic $\mathrm{CO}_{2}$ storage is located in the Cretaceous-age Eutaw formation. This location has a high permeability sandstone with 60 feet of inter-formational shale seal at 7,500 feet of depth. A considerable number of wells have been drilled through the Eutaw saline aquifer formation near the potential $\mathrm{CO}_{2}$ storage site. These wells will provide valuable information on conducting the initial pre-drilling evaluation of the formation and for designing the testing, monitoring, and drilling program.

\subsubsection{Permitting Requirements}

SECARB will ensure that the test site permitting requirements of the state and local area are fully satisfied, that NEPA, Environmental Assessment (EA), and Environmental Impact Statement (EIS) requirements are met, and that a valid $\mathrm{CO}_{2}$ injection and storage permit is obtained. In compliance with these requirements, the SECRAB team will:

- $\quad$ provide a roadmap for permitting the saline aquifer field test site in the region;

- consult with federal and state regulatory permitting agencies for guidance and information;

- satisfy the local, state, and federal permitting requirements to conduct the saline aquifer test site project, including transportation, storage monitoring, and risk assessment; and

- track changes to the regulatory requirements for sequestration in the region.

The field test team is highly experienced in permitting and UIC issues. The team will analyze permitting options as well as the logistics of $\mathrm{CO}_{2}$ and flue-gas injection under current UIC guidelines. The analysis will identify regulatory pathways for $\mathrm{CO}_{2}$ sequestration and will identify areas where state oil and gas boards and/or federal UIC regulations should be adjusted to accommodate $\mathrm{CO}_{2}$ sequestration activities.

\subsection{ACTION PLANS}

As part of SECARB's Phase II Action Plan, the team will continue to refine Phase I concepts and will begin to validate, through field testing, sequestration technologies and corresponding infrastructure approaches related to regulatory, permitting, and outreach. The multi-partner collaborations that developed during Phase I will continue in Phase II. 
SECARB's Action Plans embrace three diverse field tests. Each field test can be broken down into five activities: project definition, design, implementation, operations, and closeout/reporting. In addition, the Action Plans include work in continued characterization; cross-cutting services for education and outreach; regulatory issues and permitting; monitoring, measurement and verification technology deployment; geographical information systems data presentation; and project management.

During the first year of activity, the project field teams will assess respective geologic formations to identify site-specific opportunities for field validation. As part of this downselection process, the teams will conduct environmental reviews and determine what actions are required to gain approval for site-specific field investigations.

\subsection{Field Test 1 (FT1): Gulf Coast Stacked Storage Action Plan}

FT1 is an expansion of work completed under Phase I by SECARB. The project focuses on oil and gas reservoirs and brine formations to demonstrate advanced methods of $\mathrm{CO}_{2}$ injection and monitoring for EOR and long-term geologic storage. Because of the large number of potential EOR projects as well as the large number of saline reservoirs, the Gulf Coast is the area of focus for this field test. Figure 9 shows the target area.

\subsubsection{Project Definition}

This field test is designed to evaluate the potential for injecting $\mathrm{CO}_{2}$ into multiple horizons, coupling an EOR effort to provide an economic benefit to the project with sequestration efforts in saline reservoirs "stacked" in close proximity.

Each field under evaluation will have an initial reservoir characterization completed, and a preliminary $\mathrm{CO}_{2}$ injection simulation will be performed. Candidate fields will be narrowed to one site for the field test. Field-wide simulation will be performed for the amount of $\mathrm{CO}_{2}$ to be injected, and the models recalibrated for any changing reservoir parameters. As FT1 goes into full field injection, the simulation model will be validated and updated as necessary through injection and post injection phases, with a final summary on how accurately the simulation predicts $\mathrm{CO}_{2}$ injection flow and subsequent oil volumes produced.

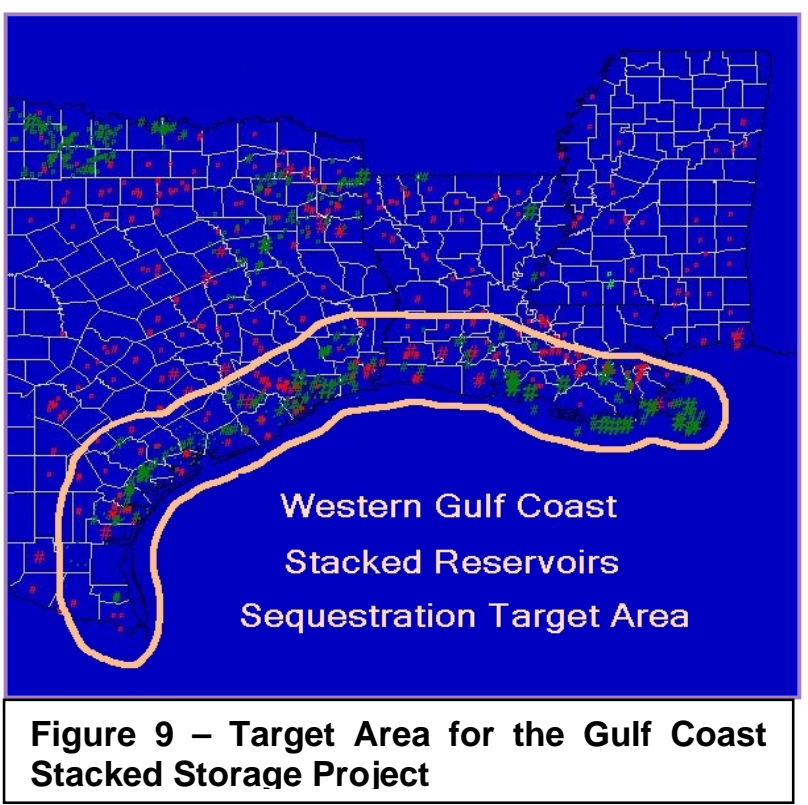

Public outreach is key to a successful

Phase II $\mathrm{CO}_{2}$ injection project. As archived in the Frio Brine Pilot project, SECARB envisions significant interaction and education of the local and regional stakeholders in this process. These parties will include several NGO's, such as the Environmental Defense Fund, National Resources Defense Council, Houston Sierra Club, and Texas Nature Conservancy. In addition, communication with local residents, schools, 
newspapers, and governmental institutions will occur.

\subsubsection{Design}

The Gulf Coast team will determine preinjection baseline characterization of $\mathrm{CO}_{2}$ concentrations that are considered normal. Subsurface characteristics of oil and brine reservoirs also must be determined prior to drilling in order that fluid changes are verified at depth after injection. Specific reservoir characteristics, such as structural dip, depositional stratigraphy and internal fluid type with specific temperature and pressures will be determined. Technical design of the pilot $\mathrm{CO}_{2}$ injection project will occur over the first two years of the project. The design will focus on assessing an optimal operating oilfield site for both oil reservoir injection and brine injection over time.

\subsubsection{Implementation}

The field team will reuse existing infrastructure (road, well, and well pads) as much as possible to minimize environmental impact and reduce cost. New surface installations will be minor and include one or two new wells, most likely placed on existing pads, and an array of low-impact, surface monitoring stations with small cement pads or markers for repeat surface surveys. SECARB will work with regional experts to ensure that the engineering is excellent and all regulatory and health and safety requirements are met.

Observational wells will be installed to observe $\mathrm{CO}_{2}$ concentration changes and associated pressure and temperature variations during injection. A critical aspect is the impact of $\mathrm{CO}_{2}$ at depth on fault-seal integrity. The injection well will undergo completion to ensure hole integrity, to guarantee that the $\mathrm{CO}_{2}$ is injected into the correct reservoir interval, and that the interval of interest can be traced to other well bores. Workover of any existing production wells and using idle wells for monitoring will be employed as needed to maintain seal integrity of the reservoir while minimizing project costs. Surface access will be obtained to facilitate the installation of shallow, vadose-zone monitoring wells to validate that no $\mathrm{CO}_{2}$ has infiltrated from the injection level to the shallowdrinking-water or surface-water zones. The reservoir container will be characterized to determine optimal injection criteria as well as logging responses expected during injection in monitoring and producing wells. The core analysis performed will address these issues.

\subsubsection{Operations}

Injection operations will be similar to those performed at the Frio Brine Pilot site. At the site, the $\mathrm{CO}_{2}$ will be repressurized to the required reservoir conditions utilizing Praxair injection equipment and processes. The experiment is planning on injection of up to 15,000 tons of $\mathrm{CO}_{2}$ over a five-month period at 3,000 tons per-month. Longer-term considerations of using low-pressure pipeline facilities at specific sites will be considered where practical but are not anticipated to be economically feasible for the field test, only for post-test, full-injection implementation.

In the stacked storage experiment, SECARB will build on the Frio Brine Pilot experience to define effective monitoring strategies for the interaction of $\mathrm{CO}_{2}$ injection with faults; distribution of pressure in the near and far field during and after injection; and impact on fluid flow and deformation. It is critical to conduct a successful $\mathrm{CO}_{2}$-EOR project in order 
to fund injection at a scale sufficient to support the monitoring strategy. The following tools will be assessed prior to field activity, and those proving viable will be fielded:

- a cased, low-angle observation bore hole that crosses the sealing fault and accesses $\mathrm{CO}_{2}$ plume development and sweep;

- pressure, temperature, and environmental management tools permanently installed with the casing of this observation well;

- a suite of open- and cased-hole logs repeated through time in all available well bores to monitor plume evolution and observe any changes above the injection zone;

- an array of tilt meters on the surface and/or down hole;

- injected suites of partitioning and nonpartitioning tracers in brine and $\mathrm{CO}_{2}$ to track fluid interactions and migration;

- near-surface monitoring for gas composition and tracer; and

- ecosystem monitoring for any impact related to $\mathrm{CO}_{2}$ leakage.

In addition, SECARB will assess the feasibility of detecting $\mathrm{CO}_{2}$ using down hole, crosswell or surface geophysics in the selected well configuration. If these seismic methods could contribute, SECARB will seek additional funding to field the instrument. Three groups of instrument designers will work with the team during the first year: Lawrence Livermore National Lab; Lawrence Berkeley National Lab; and the Diagnostic Instrumentation Analysis Laboratory (DIAL) at Mississippi State University (MSU).

Risks to the success of this project are in three main areas: health and safety; tool failure; and leakage of $\mathrm{CO}_{2}$ out of the reservoir interval. Health and safety aspects will follow all current Occupational Safety and Health Administration (OSHA) and state regulations for the transport of $\mathrm{CO}_{2}$, its injection, and operation of all associated equipment. The ability to acquire meaningful measurements for each experiment will determine the project's success. Pre-drilling modeling of reservoir conditions and collection of previously determined production and reservoir data will be utilized to define reservoir and bore hole conditions to allow the proper calibration of tools to those conditions. Much of the experiment will focus on the placement of both down hole and surface monitoring tools that will be state of the art in detecting small changes in $\mathrm{CO}_{2}$ concentrations.

SECARB will determine the preferred method of transporting $\mathrm{CO}_{2}$ to the selected field. Two options include compressed liquid via truck or barge and low-pressure gas via existing pipeline. $\mathrm{CO}_{2}$ will be an essentially pure commercial product. SECARB will continue to evaluate emerging capture options, both in industrial and power plant settings, which are critical to long-term applications of the technology.

Injection of $\mathrm{CO}_{2}$ (a key milestone) will start only after an environmental review has been conducted. The project plan calls for a minimum of 7,500 tonnes of $\mathrm{CO}_{2}$ and up to 15,000 tonnes of $\mathrm{CO}_{2}$ for injection. The injection operator will maintain the safety environment for the project and will collect all injection data as to volume, rate, and pressures utilized. This information will validate injection and production models for tracking injection fronts and production efficiencies across the field. SECARB will 
perform post-injection assessments. Information collected will be utilized in validating injection and producing models for tracking injection fronts and production efficiencies across the field. Monitoring will continue for an extended time after injection, both in the subsurface to determine storage of the $\mathrm{CO}_{2}$ and at the surface to ensure that escape of $\mathrm{CO}_{2}$ from the subsurface injection area does not occur. During the course of the project, the SECARB team will engage local media, interested governmental bodies, and local residents.

\subsubsection{Closeout/Reporting}

At the conclusion of the project, a post operation discussion of activities and results will be presented to DOE and other interested parties. Discussions will continue with the local operator on continued use of the field site for experimentation on other possible projects and to determine whether EOR aspects were successful enough for the operator to move to a full-phase recovery project. If this does occur, then interaction with the operator and supplier of $\mathrm{CO}_{2}$ for longer range storage projects will continue.

\subsection{Field Test 2 (FT2): Coal Seams Action Plan}

The action plan focuses on coal seams with high methane content and unminable coal seams in the vicinity of existing coal fields extending from the Appalachian range, southwesterly into the Black Warrior Basin and towards the Gulf Coast. This field test will demonstrate $\mathrm{CO}_{2}$ injection for ECBM in the southeastern United States. Also, this field test will investigate $\mathrm{CO}_{2}$ sequestration in unminable coal seams and address a breakthrough concept for sequestering a full range of coal-fired power plant

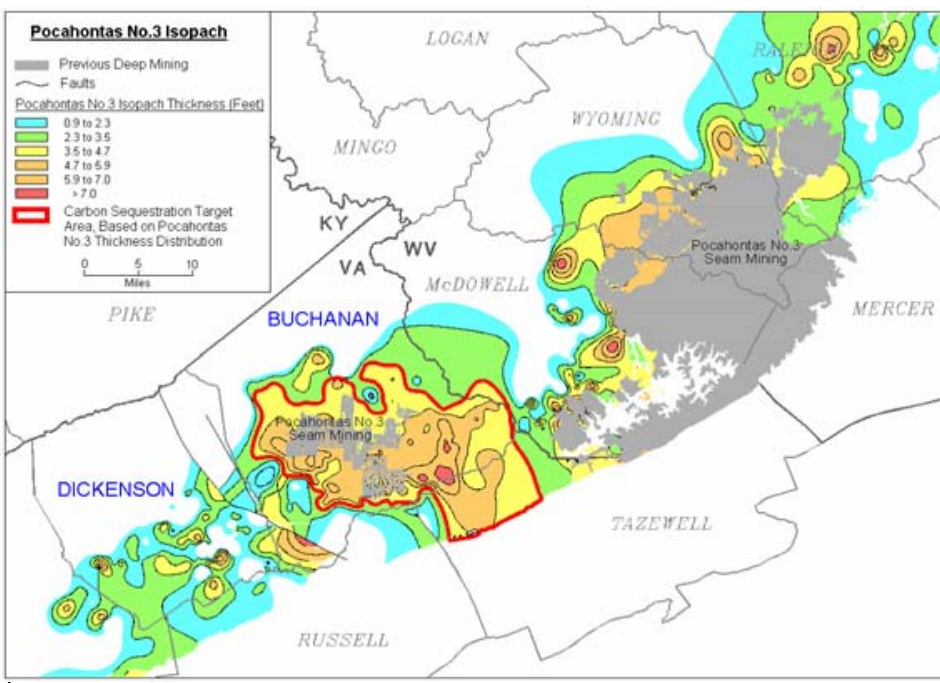

Figure 10 - Pocahontas No. 3 Seam Thickness Isopach

emissions. Two field test areas have been identified, one in the Central Appalachian Basin of Virginia, West Virginia, and Kentucky and one in the Black Warrior Basin of Alabama. These areas are shown in Figures 10 and 11 respectively.

\subsubsection{Project Definition}

Geological assessment of coal seams and GIS development will continue. The Black Warrior Basin has been assessed in detail; however, similar assessments are lacking for some areas of the Central Appalachian Basin and for the coal fields of the Alabama thrust belt. Regional characterization activities will focus on sequestration potential of CBM reservoirs in the Cahaba and Coosa coal fields of the Alabama thrust belt, where no assessments of sequestration and ECBM potential are available. Regional geologic mapping for the Central Appalachian Basin will be expanded into neighboring counties in 
Kentucky and southern West Virginia.

SECARB will review characterization study results to determine optimum sites for core hole drilling and testing for pilot injection of $\mathrm{CO}_{2}$. Approximately four well sites in both Central Appalachia and Alabama will be reviewed for possible selection as pilot sites. The results of geological characterization will be used to select the final test sites and to determine the precise well design and monitoring plan.

Reservoir modeling is an important component in understanding the

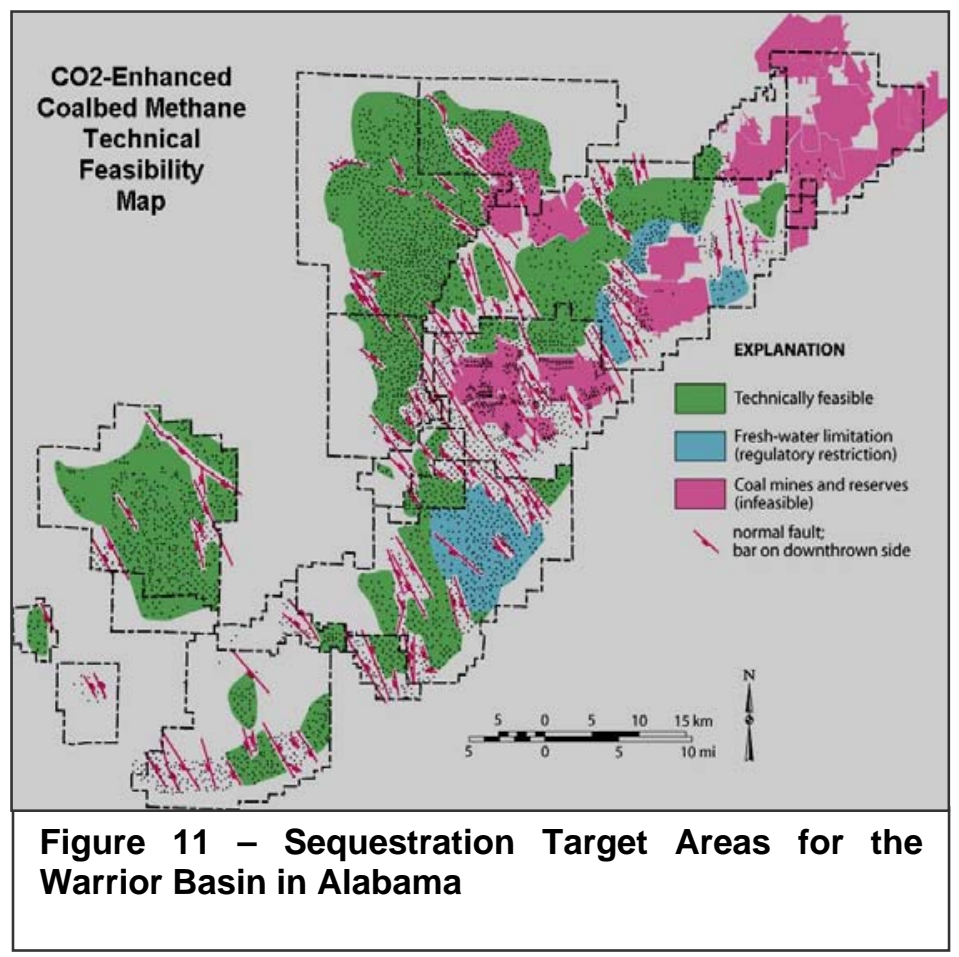
mechanisms at work in carbon sequestration within coal seams. As such, the process will require the gathering of production history and detailed geologic information for each of the prospective pilot locations. A history match will be synthesized from these data. Multiple sensitivity runs then will be conducted concerning the injection of $\mathrm{CO}_{2}$ (rate, pressure, and duration) and production controls at offset producers (rate, pressure), which should contribute to the design aspect of the pilot by providing estimates of the necessary $\mathrm{CO}_{2}$ volumes, expected operating conditions, and a baseline expectation.

The public outreach and education activities for the Coal Seam Project should be initiated early and span the entire schedule, beginning with the assembly of an advisory committee at the start of the project that will include a broad range of stakeholders, including gas producers, utilities, regulators, and landowners. A vigorous technology transfer program will be conducted throughout Phase II and will include development of a project website, presentations at technical meetings, and publications. A local outreach program in both Alabama and Central Appalachia will develop a grassroots group to enlighten citizens in the area on the positive benefits the sequestration program offers. A speaker's bureau will be created to engage and educate elected officials (local, regional, state), chambers of commerce, civic organizations, and educational communities through printed publications and PowerPoint presentations.

\subsubsection{Design}

Four types of reservoir modeling efforts provide the basis for design:

- review of the selected primary injection site's basins;

- $\quad$ rigorous history matching and assessment of the preferred $\mathrm{CO}_{2}$ injection sites;

- mid-course reservoir modeling to assess the performance of the project against 
expectations; and

- post-project history matching and performance prediction of the $\mathrm{CO}_{2}$ sequestration pilots and their implications to $\mathrm{CO}_{2}$ storage in the basins.

After the locations of the test sites are determined, three core holes will be drilled around each production well and the specific pilot design will be determined on the basis of the baseline reservoir models.

\subsubsection{Implementation}

This program will make use of existing CBM wells. Therefore, the principal construction requirements under this program will be the drilling of core holes and the installation of monitoring apparatus. Field work will not begin until an environmental review has been completed. Three core holes will be drilled around the production well immediately after the location of the test site is finalized. These holes will be about 75 to $150 \mathrm{~m}$ from the production well, and the precise locations will be determined on the basis of the baseline reservoir models. After the cores are removed for analysis, the core holes will be converted into monitor wells. A similar monitoring design was employed at the Rock Creek test site in the Black Warrior Basin, which was used to develop CBM completion technology (Spafford and Stubbs, 1989; Koenig, 1989). Isolation packers and slim hole monitoring equipment will be installed to observe reservoir pressure and gas composition. Shortly thereafter, shallow slant holes will be drilled and monitoring equipment will be installed to analyze gases in near-surface fractures.

Risk analyses will be performed and include review of the feasibility of the proposed pilot tests and assessment of environmental risks. Integration of geologic, geophysical, laboratory, reservoir, and production data will be necessary to complete this task. Monitoring and verification implementation will focus on two approaches: (1) deep well monitoring; and (2) shallow subsurface monitoring. To prepare for field testing, the core holes will be converted to deep monitor wells by an oilfield service company, and three shallow wells will be drilled for shallow monitoring in the Black Warrior Basin pilot. Baseline data will be collected for a minimum of three months before injection-falloff and production testing begins. Monitoring equipment will be installed in the shallow wells to monitor $\mathrm{CO}_{2}$ levels. Baseline data on natural $\mathrm{CO}_{2}$ levels will be measured for at least three months prior to deep well testing. Any required leases, surface owner agreements, state drilling permits, and Class II permits from the EPA will be obtained prior to implementation.

\subsubsection{Operations}

A sequence of parallel tests will be performed in Alabama and Central Appalachia in order to allow proper evaluation of each basin. These tests will be staggered to allow for proper funding and minimize replication among the proposed pilot tests. Pilot project operations will constitute a series of injection-falloff and production tests similar to those performed by the Alberta Research Council (Law, 2004). The total amount of $\mathrm{CO}_{2}$ required for each injection program is estimated to be 1,000 tons. However, higher injection volumes are anticipated for the horizontal multi-lateral injection pilot in the Central Appalachian region. Reservoir pressure and gas composition will be monitored in the deep monitor wells throughout the injection testing. Deep monitoring will continue for at least three months after the injection tests are completed. Similarly, gas 
composition will be monitored in the shallow monitor wells at the Alabama site throughout the injection tests, and shallow monitoring also will continue for at least three months after the injection tests are completed to ensure that no leakage occurs.

Injection operations at each of the proposed coal seam test sites will comprise a series of injection-falloff and production tests similar to those performed by the Alberta Research Council in Canada and China (Law, 2004). Prior to injection, a production and pressure-buildup test will be performed in three separate coal zones to analyze pressure response and permeability near the production well. Next, a 10- to 15-ton slug of $\mathrm{CO}_{2}$ will be injected into each coal zone to determine the pressure-falloff response of the reservoir to $\mathrm{CO}_{2}$, and then a second set of production tests will be performed. After this, a larger slug of up to 100 tons of $\mathrm{CO}_{2}$ will be injected and pulsed injection tests performed. Additional injection tests will follow this step, and the size and timing of these tests will be determined on the basis of the initial results of production and injectionfalloff testing. A final production test will be performed to analyze changes in reservoir properties after the injection tests are complete. The total amount of $\mathrm{CO}_{2}$ required for each injection program is estimated to be 1,000 tons. However, the test procedure and $\mathrm{CO}_{2}$ requirement may be changed somewhat for the multi-lateral horizontal test after initial modeling is complete.

Monitoring and verification will focus on deep well monitoring and shallow subsurface monitoring. After the three core holes are drilled at each test site, they will be converted into deep monitor wells. Packers will be installed to isolate three separate coal zones. Slim hole equipment for observing reservoir pressure and gas composition will be installed between the isolation packers to monitor reservoir pressure and gas composition $\left(\mathrm{CO}_{2}\right.$ and $\left.\mathrm{CH}_{4}\right)$. Baseline data will be collected for a minimum of three months before injection-falloff and production testing begins, and data will continue to be collected during the well testing and for at least three months after the testing is completed. Pressure response and gas composition will be mapped using the data from the observation wells, and reservoir models will be refined on the basis of the data.

Southern Company Services (SRS) will perform surface and shallow subsurface monitoring in Alabama consisting of approximately 30 surface sampling stations and three shallow wells that will be drilled directionally. Infrared gas analyzers with accumulation chambers will be used to measure $\mathrm{CO}_{2}$ flux using the methods of Ghafurian et al. (1998) and Galdiga and Greibrokk (2000). The three wells will be drilled into bedrock below the soil zone to analyze gases in fractures and to minimize falsepositive $\mathrm{CO}_{2}$ readings caused by bacterial action within the soil profile. Baseline data on natural $\mathrm{CO}_{2}$ levels will be measured for at least three months prior to deep well testing, and testing will continue for at least eight months after the injection-falloff and production tests are completed. One shallow monitor well will be drilled near the production well to test for leakage near the injection site, another will be installed above the main hydraulic fractures that extend laterally from the production well, and a third will be installed in a location remote to the production well and other monitor wells.

The principal risks associated with the injection experiments are leakage of $\mathrm{CO}_{2}$ and dilution of $\mathrm{CH}_{4}$ with $\mathrm{CO}_{2}$ in nearby production wells. The small amount of $\mathrm{CO}_{2}$ required for the injection tests will minimize risk by limiting the probability of leakage. Also, the small amount of $\mathrm{CO}_{2}$ to be injected under this program should not travel more than 150 meters from the well bore and thus should not affect the quality of gas produced in 
nearby wells. The deep monitoring program for gas composition will be sufficient to determine if communication of gas between coal zones occurs. The shallow monitoring program, similarly, will be used to determine if seepage of injectate at the surface is a problem at the Alabama pilot. If surface seepage is a problem there, then injection rates will be reduced, or the injection tests will be terminated. If communication between coal zones occurs, injection pressures and volumes will be adjusted to minimize communication.

$\mathrm{CO}_{2}$ will be purchased from a commercial source. Transportation to the well site will be by tanker trucks, which hold up to 30 tons of $\mathrm{CO}_{2}$. The $\mathrm{CO}_{2}$ will be warmed to surface temperature and injected directly from the trucks. The $\mathrm{CO}_{2}$ that is used in the injection tests will be relatively pure and contain no significant impurities that will impact the project results. An identified supplier of bulk liquid $\mathrm{CO}_{2}$ is Praxair in Marietta, Ohio. From Marietta, the $\mathrm{CO}_{2}$ will be shipped by tanker truck to the proposed pilot area in Central Appalachia.

A sequence of parallel tests will be performed in Alabama and Central Appalachia in order to allow proper evaluation of each basin. These tests will be staggered to allow for proper funding and minimize replication among the proposed pilot tests. Pilot project operations will constitute a series of injection-falloff and production tests similar to those performed by the Alberta Research Council (Law, 2004). The total amount of $\mathrm{CO}_{2}$ required for each injection program is estimated to be 1,000 tons. However, higher injection volumes are anticipated for the horizontal multi-lateral injection pilot in the Central Appalachian region. Reservoir pressure and gas composition will be monitored in the deep monitor wells throughout the injection testing. Deep monitoring will continue for at least three months after the injection tests are completed. Similarly, gas composition will be monitored in the shallow monitor wells at the Alabama site throughout the injection tests, and shallow monitoring also will continue for at least three months after the injection tests are completed to ensure that no leakage occurs.

\subsubsection{Closeout/Reporting}

The Coal Seam team will interpret the results of deep and shallow monitoring and refine reservoir models using the injection-falloff and production data and obtain a history match. A base forecast will be supplied to understand the potential movement of $\mathrm{CO}_{2}$ over geologic time. Various sensitivity parameters will be reviewed, such as caprock permeability and vertical permeability within the coals to aid in the understanding of longterm storage and migration of $\mathrm{CO}_{2}$ within coal seams. The results of injection testing will identify best practices for $\mathrm{CO}_{2}$ sequestration, vertical versus horizontal well injection efficiencies, ECBM, monitoring, and regulation. Well tests and model results will be used to revise procedures for assessing sequestration capacity and ECBM potential in other coal basins. The proposed injection tests for $\mathrm{CO}_{2}$ constitute an early step in realizing the acid-gas sequestration potential of coal. Modeling efforts and analysis of regulatory factors also will explore the possibility of sequestering multiple acid gases in coal, a breakthrough technology with the potential for low cost, permanence, and large global capacity.

\subsection{Field Test 3 (FT3): Saline Formation Action Plan}

Field Test 3 focuses on the ultimate goal of locating suitable geologic sequestration 
sinks in proximity to large coal-fired power plants. Funds will be used specifically for investigating the geologic formations in proximity to EPRI's proposed Test Center. The Test Center team will assemble the available deep well logs, core analyses, and other geological data to build a geologic and reservoir model. The team will use its COMET2 reservoir simulator to estimate $\mathrm{CO}_{2}$ injectivity plus long-term $\mathrm{CO}_{2}$ storage capacity and fate. The team also will run the models for a longer time period to fully assess the $\mathrm{CO}_{2}$ storage potential of the saline aquifers in this area.

\subsubsection{Project Definition}

The Test Center team will specify the well pad and infrastructure criteria, prepare the drilling, casing and completion plan, define the surface facility requirements, identify the reservoir characterization and testing plan for the injection and monitoring wells, and conduct numerous other pilot test site planning and preparation tasks. The team will: (1) support Southern Company and the local plant management involved in the test site project with initial information and distribution materials on the proposed project; and (2) work with Southern Company to prepare an action plan for informing the public and gaining their acceptance.

The FT3 team will build a detailed geological and reservoir model of the proposed test site, including conducting a sequence of reservoir simulations to estimate injectivity, storage capacity, and the long-term fate of injected $\mathrm{CO}_{2}$. The project will assemble the available deep well logs, core analyses, and other geological data to build a geologic and reservoir model of the proposed saline aquifer test site. The Test Center team will use the COMET2 reservoir simulator to estimate the $\mathrm{CO}_{2}$ injectivity and the long-term $\mathrm{CO}_{2}$ storage capacity and fate of the injected $\mathrm{CO}_{2}$ of the site. The team will run the model to match the injection rate and flow performance of $\mathrm{CO}_{2}$ injection at the test site to conduct a "history match" that will provide confidence in the $\mathrm{CO}_{2}$ storage properties of the Eutaw formation in the plant area. Next, the model will be executed for much longer time periods and for a larger geographic area to predict the $\mathrm{CO}_{2}$ storage potential of the Eutaw saline aquifer in this portion of the SECARB region.

To help define the $\mathrm{CO}_{2}$ storage potential of the area, a sequence of four reservoir modeling efforts will be conducted during Phase II. These will be:

- initial "screening modeling" to verify the selection of the primary site;

- rigorous assessment of the preferred $\mathrm{CO}_{2}$ injection site after obtaining actual reservoir data from the slim hole monitoring well;

- numerous sensitivity runs to establish injectivity and storage; and

- mid-course reservoir modeling to assess the performance of $\mathrm{CO}_{2}$ injectivity and flow prediction.

FT3 will assist Southern Company and the local plant management with initial information and distribution materials on the proposed project. FT3 will work with Southern Company to clearly define roles for Southern Company's management staff, SECARB, and the pilot project plant staff for informing the public and gaining their acceptance. The team will provide periodic updates of the project to Southern Company and SECARB staff in a form that can be readily submitted to the public at large. FT3 will design plans using insights from the successful public outreach and education efforts by 
the DOE/NETL sponsored BEG Frio saline aquifer project in Texas and the American Electric Power's Mountaineer $\mathrm{CO}_{2}$ sequestration project in West Virginia. FT3 also will ensure that the project complies with the public involvement requirements set forth for NEPA and regulatory permitting. In addition to providing information to the public using local newspapers and media advertising, FT3 will help Southern Company hold public education programs at libraries, schools, and local businesses and provide information to and personal visits with local and state officials interested in the saline aquifers $\mathrm{CO}_{2}$ sequestration project in the SECARB region.

\subsubsection{Design}

FT3 will procure and transport approximately 3,000 tons of $\mathrm{CO}_{2}$ and inject it over 30 days of operation. The total volume of $\mathrm{CO}_{2}$ injected will depend on the costs which are projected to be $\$ 100$ per ton. The Test Center team will set forth the $\mathrm{CO}_{2}$ storage and monitoring protocols for the saline aquifer's field test site including, as appropriate, "shooting" of baseline and subsequent seismic, pressure, and fluids sampling by the observation wells and the linkage of reservoir simulation-based projections of the movement and fate of $\mathrm{CO}_{2}$ with actual observations. The MMV protocol description includes the costs of installing and operating each protocol. Test site permitting will ensure that NEPA, EA and EIS requirements are met and that valid permits are obtained. For the saline aquifer test site, the team will (1) provide a roadmap for permitting saline aquifer test sites in the region; (2) consult with federal and state regulatory permitting agencies for guidance and information; (3) satisfy the local, state, and federal permitting requirements to conduct the project, including transportation, storage, monitoring, and risk assessment; and (4) track changes to the regulatory requirements for sequestration in the region.

\subsubsection{Implementation}

The first step will be to conduct an environmental review, followed by characterization of the reservoir. A slim hole reservoir characterization well will be used to acquire subsurface data to conduct the detailed pre-injection well drilling characterization of the test site. Later, this well will be used to provide future reservoir access for monitoring and observing the flow and storage of $\mathrm{CO}_{2}$ in the Eutaw saline aquifer. As part of the slim hole well reservoir characterization effort, a full suite of geophysical logs will be obtained, pressure transient testing on reservoir zones of interest will be conducted, and the formation and overburden stress evaluated.

The well logging will provide vital information on the porosity and net reservoir thickness of the Eutaw formation in the test site area, which is essential for estimating the $\mathrm{CO}_{2}$ storage potential in the test site area. The pressure transient testing will provide a firstorder estimate of the reservoir permeability necessary for calculating $\mathrm{CO}_{2}$ injectivity in the test site area. The confining stresses of the shale formations adjacent to the primary $\mathrm{CO}_{2}$ injection zones will be evaluated to provide an assessment of the competence of the reservoir seal.

After drilling, logging, and testing of the slim hole well in the Eutaw formation, the next step will identify the specific location and prepare the well pad for the $\mathrm{CO}_{2}$ injection well. This process will involve examining the surface characteristics of the area, identifying the need for new roads or alternative site access, and establishing the size, disposal 
requirements, and environmental impacts of establishing the well site. It also will involve arranging for site clearance, well pad construction, and protective fencing. The final step is to procure the well drilling, well completion, and surface equipment for the test site.

Site-specific reservoir characterization will be conducted beginning with a slim hole reservoir characterization of wells along with well testing and analysis to acquire detailed subsurface data. A suite of geophysical logs will be obtained, and pressure transient testing on reservoir zones of interest will be conducted. The confining stresses of formations adjacent to the primary $\mathrm{CO}_{2}$ injection zones will be evaluated. The Test Center team expects three months for site preparation, well drilling, and installation of facilities. The team will define and conduct the work designed to establish the baseline conditions for the field test site, including a high resolution 2-D seismic survey, soil sampling, reservoir fluid sampling, and the characterization of the reservoir seal and bounding layers.

\subsubsection{Operations}

As part of this effort, the FT3 team will specify the $\mathrm{CO}_{2}$ injection and testing plan for the injection and monitoring wells. The current plans are to inject approximately 3,000 tons of $\mathrm{CO}_{2}$ and to observe its movement and storage in the saline aquifer formation. The team will review these plans with the outside experts to ensure that the injection and monitoring expectations are sound. Particular attention will be given to avoiding and reducing well bore corrosion problems from the acidic $\mathrm{CO}_{2}$ and water solution during the injection of $\mathrm{CO}_{2}$.

The FT3 team will set forth the $\mathrm{CO}_{2}$ storage and monitoring protocols for the saline aquifers field test site. This will include, as appropriate, baseline and subsequent seismic surveys, pressure, and fluids sampling by the observation wells, and the comparison of reservoir simulation-based projections of the movement and fate of $\mathrm{CO}_{2}$ with actual observations. The team will define and supervise the implementation of work designed to establish the baseline conditions for the field test site. This will include conducting a high-resolution 2-D seismic survey, soil sampling, reservoir fluid sampling, and the characterization of the reservoir seal and bounding layers. The current plan is to shoot two ten-mile 2D seismic lines over the field test site, to provide the important "baseline." This will be followed by shooting two additional ten-mile seismic lines after $\mathrm{CO}_{2}$ injection to track the movement and storage of the $\mathrm{CO}_{2}$. The fluid sampling plan will include taking fluid measurements in the monitoring well to gain an understanding of $\mathrm{CO}_{2}$ saturation in the field test site area.

Risk analysis will include examination of the pilot project operation and assessment of future environmental risks. This task will be conducted and performed as an EA, reviewing the potential risks relevant to a given pilot site(s). Integration of geologic, geophysical, laboratory, reservoir, and production data will be necessary to complete this task. Highlights of this analysis should consider caprock integrity, quality of stored $\mathrm{CO}_{2}$, movement profile, MMV, and duration of storage, with significant portions of this information being derived from the reservoir modeling. More specifically, this task will review and assess the potential economic and environmental risks involved in pilot and large-scale $\mathrm{CO}_{2}$ injection projects due to contamination of offset wells, carbonic acid induced corrosion, contamination of groundwater or other horizons, and possible facility incidents. Land, regulatory, safety, operational, gas processing, and logistical issues that 
could present obstacles to pilot or large-scale implementation projects also will be reviewed.

The FT3 team's preliminary plan is to purchase 3,000 tons of $\mathrm{CO}_{2}$ and transport it under pressure to the test site. While we have yet to establish the source of $\mathrm{CO}_{2}$, FT3 has identified a number of viable options, including ethanol plants, refineries, fertilizer plants, and gas processing plants in the area. We also are familiar with Denbury's plans to extend their $\mathrm{CO}_{2}$ transportation line south. This provides the test site a back-up source of $\mathrm{CO}_{2}$ should industrial sources of $\mathrm{CO}_{2}$ not be available or too costly.

Based on the volume of $\mathrm{CO}_{2}$ to be injected, the test site will operate actively for 30 days, with monitoring and passive operations to follow. Selected MMV protocols, including a second high resolution 2-D seismic survey, will ensure that the sampling plan, frequency and number of samples taken, and the overall operations of MMV at the saline aquifer test site meet the protocol design. Mid-course reservoir modeling will assess the performance of the project and its implications to $\mathrm{CO}_{2}$ storage in the basins.

The Test Center team will provide detailed analysis to establish the economic and $\mathrm{CO}_{2}$ storage implications for the overall SECARB region learned from the performance of the test site. The economic model will be used to extrapolate the results from the pilot to basin-scale. The Test Center team will prepare the saline aquifers test site chapter and develop the MMV protocols and performance chapter for the SECARB Final Report.

\subsection{References}

Arthur, J.K., and Taylor, R.E., 1990, Definition of geohydrologic framework and preliminary simulation of ground-water flow in the Mississippi embayment aquifer system, Gulf Coastal Plain, United States: U.S. Geological Survey Water-Resources Investigations Report 86-4364, 97 p.

Dodge, M. M. and Posey J. S., 1981, Structural Cross Sections, Tertiary Formations, Texas Gulf Coast, Bureau of Economic Geology Cross Section Set CS0002, 5 p, 32. plates

Galloway, W. H., Hobday, D. K., and Magara, Kinji, 1982, Frio Formation of the Texas Gulf Coast Basin-depositional systems, structural framework, hydrocarbon origin, migration, distribution, and exploration potential: The University of Texas at Austin, Bureau of Economic Geology Report of Investigations No. 122, 78 p.

Hosman, R.L., 1996,

Hendericks and others, 2002, building the cost curves for CO2 storage, IEA Greenhouse Gas R\&D Programme

Hovorka and others, 2004, Report to the Texas Commission on Environmental Quality to Accompany a Class $\vee$ Application for an Experimental Technology Pilot Injection Well: Frio Pilot in $\mathrm{CO} 2$ Sequestration in Brine-Bearing Sandstones, http://www.beg.utexas.edu/environqlty/co2seq/publications.htm

LBG Guyton Associates, 2003, Brackish Groundwater Manual for Texas regional Water Planning Groups, http://www.twdb.state.tx.us/publications/reports/GroundWaterReports/GWReports/Br ackish\%20GW\%20Manual/BrackishGWReportIndex.htm 
Pashin, J. C., Carroll, R. E., Groshong, R. H., Jr., Raymond, D. E., Mclntyre, M. R., and Payton, J. W., 2004, Geologic screening criteria for sequestration of CO2 in coal: quantifying potential of the Black Warrior coalbed methane fairway, Alabama: Final Technical Report, U.S. Department of Energy, National Technology Laboratory, contract DE-FC26-00NT40927, 254 p.

Karmis, M., Conrad M., Miller, M. and Ripepi, N., 2005, Phase I Technical Progress Report: Sequestration Strategies in Virginia and Central Appalachia.

Spafford, S. D., and Stubbs, P. B., 1989, Reservoir pressure profiles and desorption estimates for the Mary Lee coal group based on monitor well data at the Rock Creek project: Tuscaloosa, Alabama, The University of Alabama, College of Continuing Studies, 1989 Coalbed Methane Symposium Proceedings, p. 195-201.

Koenig, R. A., 1989, Hydrologic characterization of coal seams for optimal dewatering and methane drainage: Quarterly Review of Methane from Coal Seams Technology, v. 7, p. 30-31.

Law, D. H.-S., 2004, Enhanced coalbed methane recovery and carbon sequestration projects in Canada and China: single well micro-pilot tests, in Reeves, S. R., ed., Enhanced Coalbed Methane Recovery and CO2 Sequestration: Society of Petroleum Engineers Applied Technology Workshop Proceedings, unpaginated CDROM.

Ghafurian, R., Dietz, R. N., Rodenbaugh, T., Dominguez, J., and Tai, 1998, Leak location in fluid-filled cables using the PFT method: Brookhaven National Laboratory, Report BNL-65959.

Galdiga, C. U. and Greibrokk, T., 2000, Ultra trace detection of perfluorocarbons tracers in reservoir gases by absorption/thermal desorption in combination with $\mathrm{NICl}$ GC/MS: Journal of Analytical Chemistry, v. 367, p. 43-50. 